\title{
A família Solanaceae Juss. no município de Vitória da Conquista, Bahia, Brasil
}

The family Solanaceae Juss. in the municipality of Vitória da Conquista, Bahia, Brazil

Jerlane Nascimento Moura ${ }^{1 \oplus 0)} \&$ Claudenir Simões Caires ${ }^{1 \oplus 0}$

1. Universidade Estadual do Sudoeste da Bahia, Departamento de Ciências Naturais, Vitória da Conquista, Bahia, Brasil

Palavras-chave

Solanales. Taxonomia. Florística.

Nordeste.

\section{Keywords}

Solanales. Taxonomy. Floristics.

Northeast.
Recebido em: 08/07/2020

Aceito em: $15 / 12 / 2020$

Editor responsável: Gleidson V. Marques (UFSB)

eISSN: 2595-6752

\begin{abstract}
Resumo
Solanaceae é uma das maiores famílias de plantas vasculares, com 100 gêneros e ca. de 2.500 espécies, com distribuição subcosmopolita e maior diversidade na região Neotropical. Este trabalho realizou um levantamento florístico das espécies de Solanaceae no município de Vitória da Conquista, Bahia, em área ecotonal entre Caatinga e Mata Atlântica. Foram realizadas coletas semanais de agosto/2019 a março/2020, totalizando 30 espécimes, depositados nos herbários HUESBVC e HVC. Foram registradas 19 espécies, distribuídas em nove gêneros: Brunfelsia (2 spp.), Capsicum (1 sp.), Cestrum (1 sp.), Datura (1 sp.), Iochroma (1 sp.) Nicandra (1 sp.), Nicotiana (1 sp.), Physalis (1 sp.) e Solanum (10 spp.). Dentre as espécies coletadas, cinco são endêmicas para o Brasil e 11 foram novos registros para o município. Nossos resultados demonstram que Solanaceae é uma família de elevada riqueza de espécies no município, contribuindo para o conhecimento da flora local.
\end{abstract}

\begin{abstract}
Solanaceae is one of the largest families of vascular plants, with 100 genera and ca. 2,500 species, with subcosmopolitan distribution and greater diversity in the Neotropical region. This work carried out a floristic survey of Solanaceae species in the municipality of Vitória da Conquista, Babia, in an ecotonal area between Caatinga and Atlantic Forest. Weekly collections were carried out from August/2019 to March/2020, totaling 30 specimens, deposited in the HUESBVC and HVC herbaria. Nineteen species were registered, distributed in nine genera: Brunfelsia (2 spp.), Capsicum (1 sp.), Cestrum (1 sp.), Datura (1 sp.), Iochroma (1 sp.), Nicandra (1 sp.), Nicotiana (1 sp.), Physalis (1 sp.) and Solanum (10 spp.). Among the species collected, five are endemic to Brazil and 11 were new records for the municipality. Our results demonstrate that Solanaceae is a family of high species richness in the municipality, contributing to the knowledge of the local flora.
\end{abstract}

\section{Introdução}

Solanaceae Juss. é reconhecida dentro da ordem Solanales (APG, 2016) constituída com cerca de 2.500 espécies distribuídas em 100 gêneros, que apresentam grande diversidade morfológica e química (Olmstead et al., 2008; Olmstead, 2013). As principais características que definem a família são a forma de vida herbácea a lenhosa, inerme ou aculeada; folhas alternas, simples, inteiras a pinatissectas, sem estípulas; inflorescências cimosas, em fascículos ou condensadas, raro reduzidas a uma flor, comumente hermafroditas, actinomorfas ou zigomorfas, gamossépalas, 
gamopétalas, estreladas, rotáceas, rotáceo-estreladas, tubulares, infundibuliformes ou hipocrateriformes, pequenas a grandes; anteras com deiscência longitudinal ou poricida, ovário súpero e frutos do tipo baga, drupa ou cápsula (Barboza et al., 2016; Giacomin; Gomes, 2018).

É uma das famílias mais importantes economicamente, em virtude do potencial alimentício, medicinal e ornamental. Culturas como tomate (Solanum lycopersicum L.), batata (Solanum tuberosum L.), pimentamalagueta (Capsicum frutescens L.) e berinjela (Solanum melongena L.), exibem uma extensa importância na economia mundial. Grande parte das espécies alimentares da família estão distribuídas entre os gêneros Solanum L., Capsicum L. e Physalis L. (Samuels, 2015). Muitas espécies apresentam potencial farmacológico de grande valia para a medicina como Capsicum annum L., Capsicum frutescens L. (Al-Snafi, 2015); Nicandra physalodes (L.) Gaertn., Physalis angulata L. (Silva; Agra, 2005); Solanum nigrum L. (Giorgetti; Negri, 2011) e Solanum sisymbriifolium Lam. (More, 2019). Algumas espécies, como Datura stramonium L., são tóxicas, possuem princípios ativos que causam alterações fisiológicas, intoxicações em animais e humanos que podem levar à morte (Singh; Singh, 2013); outras, são utilizadas como plantas ornamentais - como Brunfelsia uniflora (Pohl.) D.Don. (Althaus-Ottmann et al., 2006); Capsicum annum L. (Stommel; Bosland, 2007); Nicotiana bonariensis Lehm. e Nicotiana forgetiana Hemsl. (Vignoli-Silva; Mentz, 2005).

A distribuição da família Solanaceae é subcosmopolita, ocorrendo principalmente na região Neotropical, e está presente em todos os domínios fitogeográficos do Brasil, sendo mais expressiva na Mata Atlântica, na Amazônia e no Cerrado (Agra et al., 2009; Flora do Brasil, 2020), colonizando geralmente áreas abertas, como clareiras, bordas de estradas ou florestas. Muitas espécies são consideradas invasoras ou daninhas, como Solanum paniculatum L. e Nicandra physalodes, as quais apresentam comportamento ruderal e ocupam ambientes desde pastagens a terrenos baldios (Guaraná et al., 2011).

Estudos apontam a América do Sul como centro de origem, endemismo e maior diversidade de Solanaceae (Hunziker, 2001; Agra et al., 2009). Estima-se que, para o continente, ocorram aproximadamente 50 gêneros endêmicos (Carvalho; Bovini, 2006). No Brasil, a família está representada por 36 gêneros e 504 espécies, das quais 237 são endêmicas. Na região Nordeste, ocorrem cerca de 21 gêneros e 189 espécies (Flora do Brasil, 2020). Dentre os gêneros que constituem a família, Solanum destaca-se por ser o mais expressivo, morfologicamente mais diversificado e economicamente importante (Sampaio et al., 2019).

Os principais tratamentos taxonômicos sobre as espécies brasileiras de Solanaceae referem-se aos trabalhos de Vellozo (1831), na Flora Fluminensis, Sendtner (1846), na Flora Brasiliensis, e Dunal (1852), em Prodromus Systematis Naturalis Regni Vegetabilis, de Alphonso de Candolle. Outras contribuições importantes foram dadas à família, como os estudos de Hunziker (2001), com uso de caracteres morfológicos, anatômicos, químicos e citológicos para a classificação das espécies, e Olmstead et al. (2008), o qual apresentou a revisão de $94 \%$ dos gêneros, com enfoque na filogenia molecular da família. No Brasil, trabalhos como Stehmann (1999), Agra (2007), Vignoli-Silva
(2009), Giacomin (2010), Knapp et al. (2015a; 2015b) e Costa-Silva e Agra (2018) são relevantes para a compreensão da família e de representantes da mesma. Mundialmente falando, a obra mais robusta sobre Solanaceae diz respeito aos estudos de Särkinen et al. (2013).

Para o Nordeste do Brasil, poucos trabalhos envolvem a taxonomia da família Solanaceae, visto que se trata de uma das famílias mais representativas, com elevado número de espécies, tornando o trabalho florístico muito mais complexo. Dentre os estudos taxonômicos já realizados, a maioria refere-se a representantes e não à família em sua totalidade. Alguns dos trabalhos que fazem menção à região Nordeste referem-se aos estudos de Agra (1992, 1999a,b, 2006, 2009), Silva et al. (2002, 2003), Zappi et al. (2003), Agra et al. (2009), Moraes et al. (2009), Barbosa et al. (2011), Giacomin e Stehmann (2011) e Sampaio et al. (2019), em síntese, apresentando a taxonomia e a diversidade da família e de espécies do gênero Solanum. Além destas, outras obras, como estudos etnobotânicos (Moreira et al., 2002; Silva et al., 2012; Pereira et al., 2016; Silva et al., 2017), farmacológicos (Lopes et al., 2006; Santos et al., 2012; Santos et al., 2016) e de composição florística (Rodal; Sales, 2007; Amorim et al., 2009; Santos; Melo, 2010), evidenciam a importância econômica, comercial e a riqueza da família. Dentre estes, os trabalhos de Agra (1992, 1999a), Moreira et al. (2002), Silva et al. (2002, 2003), Zappi et al. (2003), Amorim et al. (2009), Moraes et al. (2009), Giacomin e Stehmann (2011) e Silva et al. (2012) englobam o estado da Bahia.

Nesse contexto, o presente estudo vem apresentar um levantamento de espécies da família Solanaceae para o município de Vitória da Conquista, contribuindo para um melhor entendimento da família, gêneros e espécies que compõem a flora local. Inclui descrições, chave de identificação e pranchas fotográficas, tendo em vista que as informações nos bancos de dados mostram-se ainda bastante escassas para algumas regiões do Estado, incluindo sua porção sudoeste.

\section{Material e Métodos}

\section{Área de estudo}

O município de Vitória da Conquista (Figura 1a-b) encontra-se na mesorregião Centro Sul Baiana e microrregião de Vitória da Conquista, tendo grande parte do município situada na região do Planalto da Conquista. Vitória da Conquista está a $509 \mathrm{~km}$ da capital baiana, Salvador, e ocupa a terceira posição em densidade populacional da Bahia. Encontra-se entre as coordenadas geográficas $-40,83981^{\circ} \mathrm{S},-$ $14,84800^{\circ} \mathrm{W}$, ocupando $3.705,838 \mathrm{~km}^{2}$ de extensão territorial e 923 metros de altitude média (IBGE, 2015). Segundo a tipologia climática definida por Köppen, Vitória da Conquista está sujeita a um clima subúmido a seco ou semiárido, sendo que, para o sul do município, predomina o clima úmido a subúmido (tipo Aw e o BSwh) (SEI, 1998), com temperaturas médias mensais ou anuais entre $20{ }^{\circ} \mathrm{C}$ e $24{ }^{\circ} \mathrm{C}$, em média, e os índices pluviométricos são relativamente baixos, com média anual de precipitação equivalente a 733,9 mm (PMVC, 2019). 
Figura 1. Mapa de distribuição da família Solanaceae para o estado da Bahia (a) e para o município de Vitória da Conquista (b). Os dados de distribuição são oriundos dos herbários presentes no banco de dados do SpeciesLink no CRIA (2020).

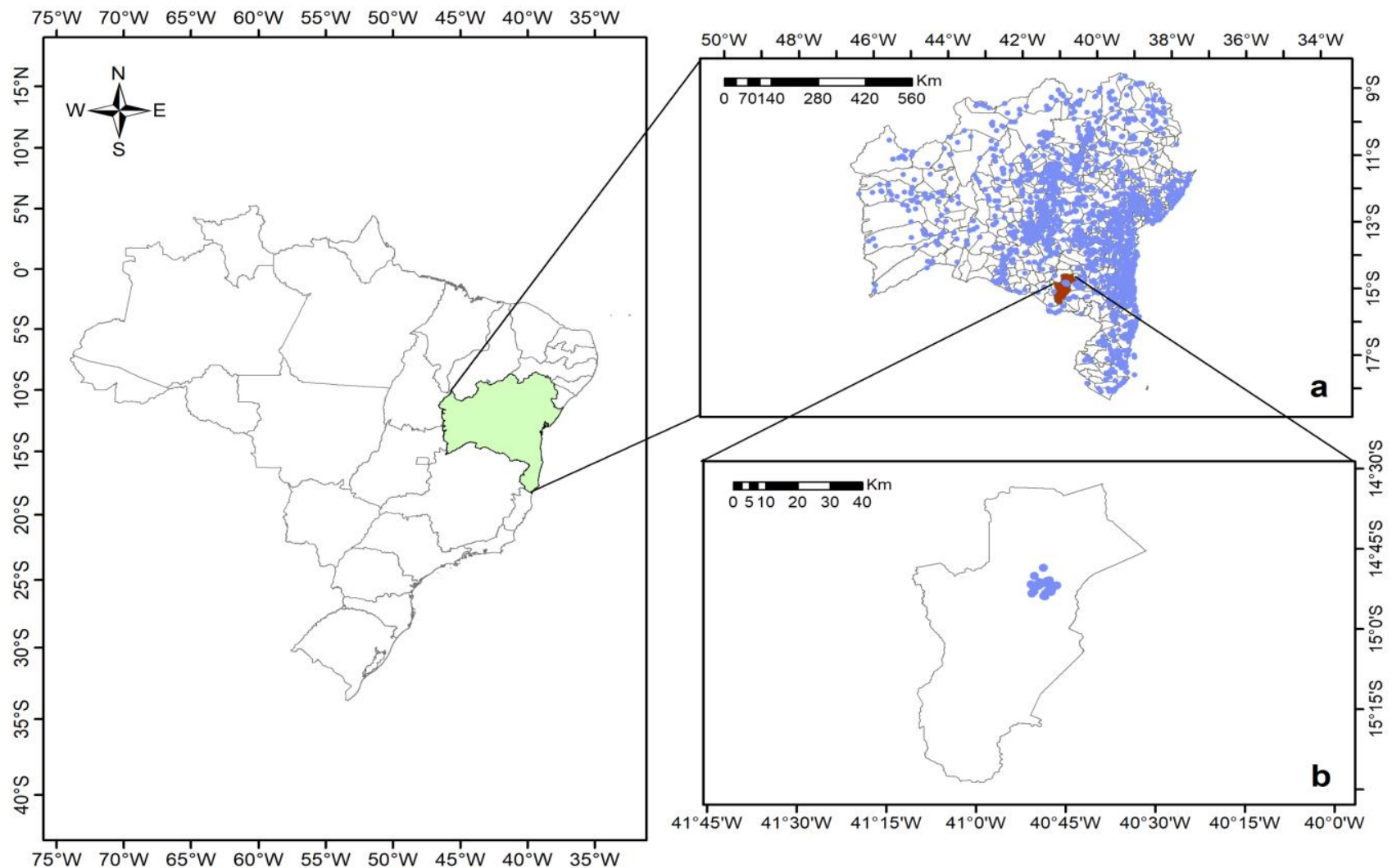

O relevo mostra-se como pouco acidentado e os biomas ocorrentes no município são representados pela Caatinga e Mata Atlântica (PMVC, 2019). A cobertura vegetal do município encontra-se bastante modificada, restando apenas fragmentos florestais (Maia, 2005). Destes, destacamos a Reserva Florestal do Poço Escuro, último remanescente de Mata Atlântica presente na cidade e que integra a Unidade de Conservação do Parque Municipal da Serra do Periperi. Outras duas áreas de proteção ambiental estão presentes no município: Parque Urbano Lagoa das Bateias e Parque Urbano da Lagoa do Jurema (PMVC, 2007).

\section{Coleta de dados e tratamento taxonômico}

Expedições e observações de campo foram realizadas semanalmente no município de Vitória da Conquista, entre os meses de agosto de 2019 e março de 2020, seguindo a metodologia de Filgueiras et al. (1994), em áreas de bordas, clareiras e interior de fragmentos florestais, bem como em locais antropizados. As amostras obtidas foram coletadas em estágio reprodutivo (flor e/ou fruto), herborizadas seguindo técnicas usuais (Mori et al., 1989), georreferenciadas e incorporadas aos acervos dos herbários HUESBVC e HVC. Dentre as áreas de estudo, as unidades de conservação também foram visitadas.
Todo material coletado foi fotografado em campo, analisado em laboratório com auxílio de microscópio estereoscópio e óptico, em seguida, foram elaboradas pranchas fotográficas das espécies.

A identificação taxonômica foi baseada na literatura especializada, como Sendtner (1846), Knapp (2002), Silva et al. (2003), Agra et al. (2009), Moraes et al. (2009), Barboza et al. (2016), Giacomin e Gomes (2018) e Sampaio et al. (2019), e através de consultas aos acervos digitais dos herbários presentes no banco de dados do CRIA 2020 (Centro de referência e Informação Ambiental https://splink.cria.org.br/) e na Flora do Brasil 2020 (http://floradobrasil.jbrj.gov.br/). Estes bancos de dados também foram consultados para informações sobre a distribuição das espécies, endemismo, hábito e novos registros.

A terminologia morfológica está de acordo com Jaeger (1985), Knapp (2002), Simpson (2010), Barboza et al. (2016) e Sampaio et al. (2019). As classificações simpodiais (unidades di, tri ou plurifoliadas), utilizadas para Solanum, seguiram o trabalho de Knapp (2002). Em Solanaceae, após o início da floração, o crescimento passa a ser simpodial, logo, cada gema apical é substituída por uma gema lateral de onde surgirá uma nova inflorescência e assim sucessivamente, sempre de cada axila da última folha. Dessa forma, todas as unidades diferenciadas em uma inflorescência fazem referência a uma unidade simpodial (Jaeger, 1985; Knapp, 2002). 


\section{Chave de identificação para as Solanaceae do município de Vitória da Conquista}

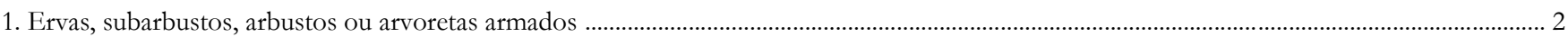

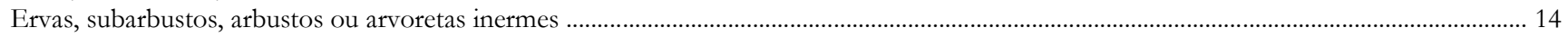

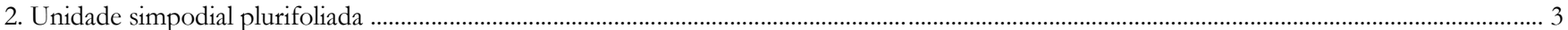

Unidade simpodial difoliada

3. Cálice fortemente armado e acrescente no fruto; epicarpo glabro, vermelho na maturidade

Solanum sisymbr

Cálice inerme não acrescente; epicarpo pubescente a tomentoso, marrom escuro ou verde na maturidade .......................................................... 4

4. Face adaxial da folha glabra ou tomentosa, verde escura; face abaxial densamente tomentosa; tricomas estrelados, sésseis ou pediculados, indumento alvo; corola lilás

Face adaxial da folha velutina a tomentosa escabra, verde ferrugínea; face abaxial velutina a tomentosa; tricomas porrecto-estrelados; corola alva a creme.

5. Face adaxial da folha glabra; face abaxial densamente tomentosa; tricomas estrelados, sésseis ou pediculados

Face adaxial da folha tomentosa, hirsuta; face abaxial tomentosa; tricomas glandulares e porrecto-estrelados

6. Ramos não alados; acúleos retos; epicarpo piloso a pubescente

Ramos alados; acúleos recurvos; epicarpo tomentoso

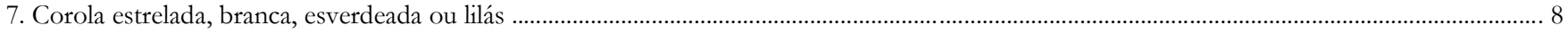

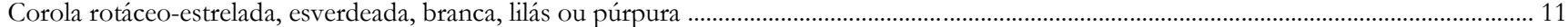

8. Corola e anteras esverdeadas ........................................................................................................................................................... Solanum agrarium

Corola branca ou lilás; anteras amarelas ou brancas ..................................................................................................................................... 9

9. Caule e ramos tomentosos a esparso-pubescentes; tricomas glandulares e estrelados; corola lilás ........................................ Solanum palinacantbum

Caule e ramos pilosos a pubescentes; tricomas simples, glandulares; corola branca a esbranquiçada ................................................................. 10

10. Folhas pilosas; corola revoluta; epicarpo amarelo na maturidade .................................................................................................. Solanum viarum

Folhas pubescentes a esparso-pubescentes; corola não revoluta; epicarpo vermelho na maturidade ........................................ Solanum stenandrum

11. Corola 4,5-5,0 cm diâm., lilás ou púrpura; baga $5,0 \times 4,7 \mathrm{~cm}$, epicarpo não glanduloso ............................................................ Solanum crinitum

Corola 1,7-2,0 cm diâm., esverdeadas a brancas; baga 0,6-1,2 × 0,4-1,1 cm, epicarpo glabro a glabrescente ……………………………...... 12

12. Folhas geminadas; cálice armado ............................................................................................................................................. Solanum asterophorum

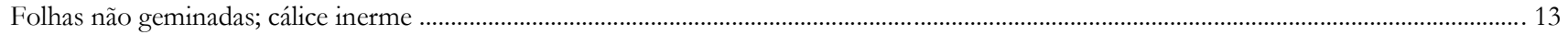

13. Cálice não ampliado no fruto; corola sem lacíneas reflexas; baga $1,2 \times 1,1 \mathrm{~cm}$................................................................... Solanum thomasiifolium Cálice ampliado no fruto; corola com lacíneas reflexas; baga $0,6 \times 0,4 \mathrm{~cm}$................................................................................. Solanum gardneri

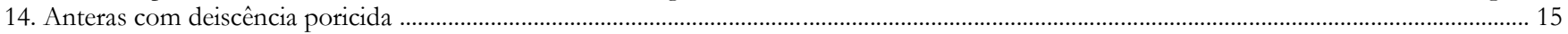

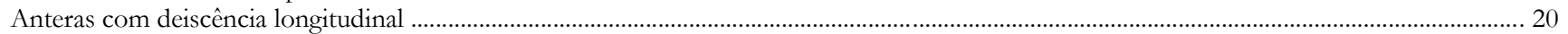

15. Folhas geminadas, dando aspecto de opostas; cálice acrescente no fruto ................................................................................... Solanum didymum

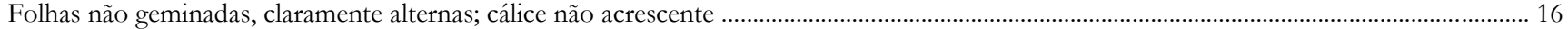

16. Baga pubescente, epicarpo verde-cinéreo quando jovem, marrom na maturidade; anteras poricidas sem fendas; com pseudoestípulas .......... 17 Baga glabra, epicarpo verde quando jovem, negro na maturidade; anteras com deiscência poricida ou terminando em fendas tardias; sem pseudoestípulas

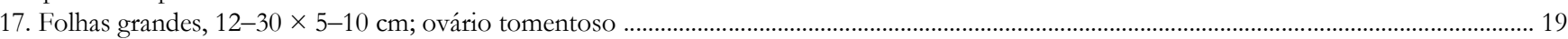

Folhas médias, 4-10 × 2-3 cm; ovário glabro ........................................................................................................... Solanum stipulaceum

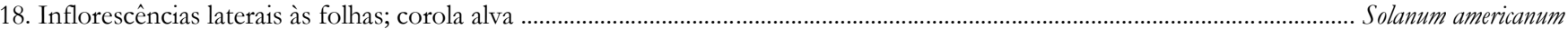
Inflorescência terminal; corola lilás a púrpura ........................................................................................................................ Solanum flaccidum

19. Indumento congesto; venação conspícua através dos indumentos; lobos do cálice sem nervuras aparentes; corola não exerta

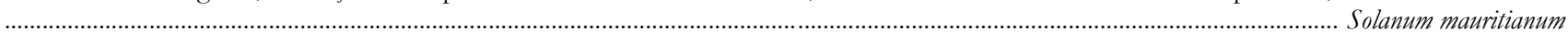
Indumento flocoso; venação inconspícua através dos indumentos; lobos do cálice com nervuras aparentes; corola exerta

Colanum granulosoleprosum

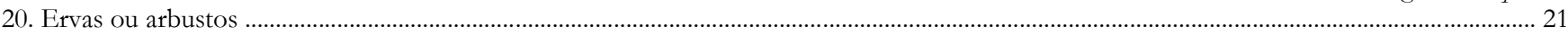

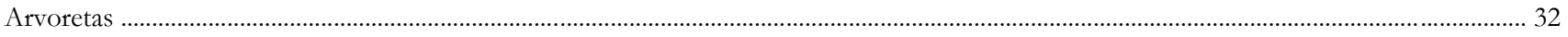

21. Corola com lóbulos intermediários; $2-4$ estames férteis ........................................................................................................................... 22

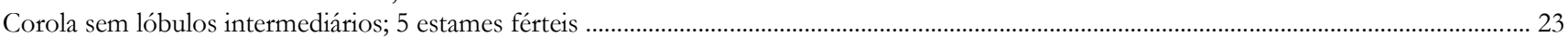

22. Folha ovado-lanceolada a cordada; corola amarela ................................................................................................................... Schwenckia molissima

Folha linear-lanceolada a oblonga; corola esverdeada a violácea ............................................................................................... Schwenckia americana

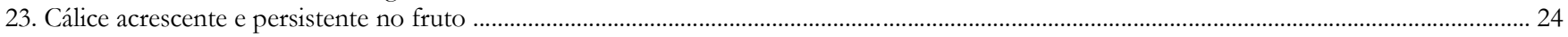

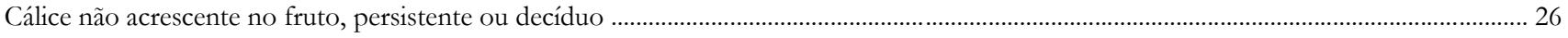

24. Caules e ramos cilíndricos; cálice livre na maior parte do comprimento; corola campanulada, lilases a alva; ovário tetralocular

Nicandra physalodes Caules e ramos angulosos; cálice fusionado na maior parte do comprimento; corola rotada-estrelada, amarela com mácula marrom; ovário bilocular

25. Caules em geral glabros; lâminas ovado-lanceoladas a oblongas; corola com máct Caules sempre com

26. Cálice circunciso; corola tubular, ovário espinescente ……………................................................................................................. Datura stramonium Cálice não circunciso; corola rotada ou hipocrateriforme; ovário não espinescente ....................................................................................... 22

27. Cálice truncado com cinco lacínias filiformes ...................................................................................................................... Capsicum baccatum

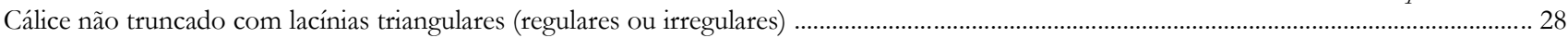


28. Flores em fascículos axilares; lobos do cálice irregulares; corola rotado-cupular, alva com manchas esverdeadas internamente

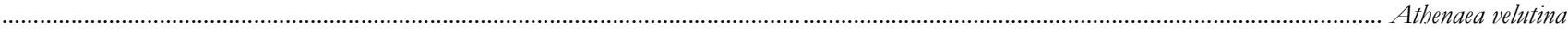
Flores em cimeiras não fasciculadas, axilares e/ou terminais; lobos do cálice regulares; corola hipocrateriforme, alternando de lilás a alva entre a antese e a senescência... 29

29. Cálice anguloso, glabro, inflado; lâminas obovadas ou oblongo-obovadas ............................................................................... Brunfelsia obovata Cálice não anguloso com tricomas, não inflado; lâminas oblongas a lanceoladas

30. Folhas lanceoladas; tricomas amarelos; 5 a muitas flores Brunfelsia brasiliensis

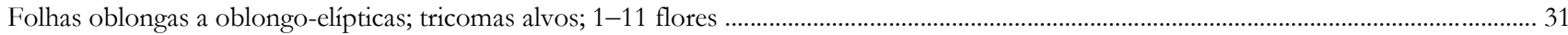

31. Pedúnculo 1-6 mm de compr.; flores solitárias com tubo da corola entre 15-25 mm de compr. ............................................... Brunfelsia uniflora Pedúnculo 11-25 mm de compr.; várias flores com tubo da corola $>25 \mathrm{~mm}$ de compr.

32. Corola amarela; frutos secos Brunfelsia pauciflora Corola branca ou creme esverdeada; frutos carnosos .... 33

33. Inflorescência fasciculada a glomeruliforme; corola branca com manchas esverdeadas; frutos globosos, alaranjados ............ Iochroma arborescens Inflorescência em cimeiras, plurifloras, não glomeruliformes; corola branco-arroxeada a creme-esverdeada; frutos ovoides, alongados, roxonigrescente

Cestrum axilare

\section{Resultados e Discussão}

Foram registrados no presente estudo 19 espécies distribuídas em nove gêneros (Brunfelsia L., Capsicum L., Cestrum L., Datura L., Iochroma Benth., Nicandra Adans., Nicotiana L., Physalis L. e Solanum L.), pertencentes aos estratos herbáceo-subarbustivo e arbustivo-arbóreo em ambientes de mata ciliar, mata-de-cipó ou antropizados (por exemplo, terrenos baldios e beira de estradas), com maior predominância do hábito arbustivo. Dentre os 19 táxons, Brunfelsia brasiliensis (Spreng.) L.B.Sm. \& Downs, B. obovata Benth., Solanum agrarium Sendtn., S. stipulaceum Willd. ex Roem. \& Schult. e $S$. thomasïfolium Sendtn. são considerados endêmicos do Brasil (Flora do Brasil, 2020).

O gênero de maior riqueza foi Solanum, com 10 espécies. Os demais gêneros foram representados por uma única espécie, exceto Brunfelsia, que se apresentou com duas espécies. A maior representatividade de Solanum é similar aos resultados observados por Moraes et al. (2009), onde o gênero representou $58 \%$ do total das espécies de Solanaceae catalogadas. Em Alves et al. (2015), Solanum obteve maior representatividade, quando comparado aos 139 gêneros listados; nos estudos de Feliciano e Salimena (2011), das 26 espécies de solanáceas registradas, 19 eram de Solanum.

De acordo com os dados do CRIA (2020), existem 17 registros de Solanaceae para Vitória da Conquista. Contudo, um estudo sobre plantas ruderais no Planalto Conquistense (Soares-Filho et al., 2016) identificou a presença de mais sete espécies de Solanaceae (Tabela 1). Dessa forma, 11 das 19 espécies registradas no presente estudo foram novas ocorrências para o município, sendo elas: Brunfelsia obovata, Cestrum axillare Vell., Iochroma arborescens (L.) J.M.H.Shaw, Nicandra physalodes (L.) Gaertn., Nicotiana glauca Graham, Physalis angulata L., Solanum agrarium, S. crinitum Lam., S. rbytidoandrum Sendtn., S. sisymbriifolium Lam. e S. viarum Dunal.

As espécies com melhores amostragens no estado da Bahia são Solanum stipulaceum, S. paniculatum L. e S. thomasiifolium (CRIA, 2020). Esses dados corroboram os resultados encontrados em campo, visto que essas espécies sempre se apresentavam em grandes concentrações e em diversos ambientes, com exceção de S. thomasiifolium, encontrado apenas em mata-de-cipó. Para Vitória da Conquista, ainda conforme o CRIA (2020), S. stipulaceum é a espécie com maiores amostragens, com sete registros, ao passo que Brunfelsia brasiliensis, Datura stramonium L. e Solanum thomasiifolium apresentam os menores valores - três, duas e duas coletas, respectivamente.

1. Brunfelsia brasiliensis (Spreng.) L.B.Sm. \& Downs, Fl. Ilustr. Catarin. [R. Reitz] 1966;1:303.

Arbusto $15 \mathrm{~cm}$ alt., ereto, inerme. Caules e ramos cilíndricos, glabrescentes, pubescência amarelada, tricomas simples. Folhas simples, discolores, sub-coriáceas, lâmina 2,5-6,4 $\times 1,2-4,0 \mathrm{~cm}$, oblongalanceolada, ápice agudo a acuminado, base atenuada, margem inteira, face adaxial pubescente ao longo da nervura, face abaxial glabrescente, ambas as faces com tricomas simples ou glandulares esparsos, diminutos, distribuídos na lâmina foliar; pecíolo $0,3-0,6 \mathrm{~mm}$ de compr., cilíndrico, puberulento. Inflorescência em cimeira, terminal, pluriflora. Botões florais não observados. Flores hermafroditas, pediceladas. Cálice campanulado, não anguloso, tubo $0,7-1,0 \mathrm{~cm}$ de compr., pubescente, lacínias triangulares. Corola alva a violeta, hipocrateriforme, tubo da corola 1,2-1,5 cm de compr., glabrescente, lobos arredondados. Anteras oblongas, deiscência longitudinal. Estigma capitado, ovário cônico. Frutos e sementes não observados.

Fenologia: coletada com flores em novembro.

Material examinado - BRASIL, Bahia: Vitória da Conquista, estrada da Barra após a entrada do Alphaville, 19/XI/2019, Moura \& Caires 15 (HUESBVC, HVC).

Brunfelsia brasiliensis é uma espécie endêmica do Brasil, distribuída pelas regiões Nordeste (BA, PI), Centro-Oeste (DF, GO) e Sudeste (ES), em domínios fitogeográficos do Cerrado e da Mata Atlântica (Flora do Brasil, 2020). Estudos evidenciam também a capacidade de adaptação da espécie na Caatinga (Carvalho et al., 2001). Na Bahia, a espécie é pouco amostrada, com registros apenas para porções da região sudoeste e sul do Estado (CRIA, 2020). A espécie coloniza frequentemente clareiras e margens de estradas e possui potencial ecológico para sobreviver mesmo com o desmatamento de florestas onde estão inseridas (Plowman, 1998; Carvalho et al., 2001). Na área em estudo, a espécie foi encontrada em um terreno aberto. 
Tabela 1. Listagem das espécies de Solanaceae ocorrentes no município de Vitória da Conquista, Bahia, Brasil, complementadas com os dados do Species-Link do CRIA $(2020)^{1}$ e do trabalho de Soares-Filho et al. (2016) ${ }^{2}$. Os dados de Endemismo (EN = Endêmica do Brasil; NEN =Não endêmica), Hábito e Domínios Fitogeográficos (AMA = Amazônia; $\mathrm{CAA}=$ Caatinga; $\mathrm{CER}=$ Cerrado; $\mathrm{MAT}=$ Mata Atlântica; PAM = Pampa) estão seguindo a Flora do Brasil 2020 em construção. Os acrônimos dos herbários seguem Thièrs (2020): ALCB = Herbário da Universidade Federal da Bahia, Campus de Ondina; CEPEC = Herbário do Centro de Pesquisas do Cacau; HUESBVC = Herbário da Universidade Estadual do Sudoeste da Bahia, Campus de Vitória da Conquista; HURB = Herbário da Universidade Federal do Recôncavo da Bahia; HVC = Herbário da Universidade Federal da Bahia, Campus Anísio Teixeira; MBM = Herbário do Museu Botânico Municipal de Curitiba; NY = Herbário de New York (USA); UB = Herbário da Universidade de Brasília; US = Herbário do Instituto Smithsonian (USA).

\begin{tabular}{|c|c|c|c|c|}
\hline Espécies (* novas ocorrências) & Voucher (herbário) & Endemismo & Hábito & Domínios Fitogeográficos \\
\hline Athenaea velutina (Sendtn.) D'Arcy ${ }^{1}$ & Santos 2504 (CEPEC) & EN & Arbusto & CAA, CER, MAT \\
\hline Brunfelsia brasiliensis (Spreng.) L.B.Sm. \& Downs ${ }^{1}$ & Moura \& Caires 15 (HVC) & EN & Arbusto & CER, MAT \\
\hline Brunfelsia obovata Benth.* & Moura \& Caires 21 (HVC) & EN & Arbusto & CAA, CER, MAT \\
\hline Brunfelsia pauciflora (Cham. \& Schltdl.) Benth. ${ }^{1}$ & Azevedo 963 (HVC) & EN & Arbusto & MAT \\
\hline Brunfelsia uniflora (Pohl) D.Don ${ }^{1}$ & Santos 2511 (CEPEC) & NEN & Arbusto & AMA, CAA, CER, MAT \\
\hline Capsicum baccatum $\mathrm{L}^{2}$ & Moura \& Caires 25 (HVC) & NEN & Arbusto & Todos os domínios \\
\hline Cestrum axillare Vell.* & Moura \& Caires 23 (HVC) & NEN & Árvore & Exceto Pampa \\
\hline Datura stramonium L. ${ }^{1}$ & Moura \& Caires 24 (HVC) & NEN & Arbusto & CAA, CER, MAT \\
\hline Iochroma arborescens (L.) J.M.H.Shaw* & Moura \& Caires 29 (HVC) & NEN & Árvore & MAT \\
\hline Nicandra physalodes (L.) Gaertn.* & Moura \& Caires 10 (HVC) & NEN & Arbusto & CAA, CER, MAT \\
\hline Nicotiana glauca Graham* & Moura \& Caires 16 (HVC) & NEN & Arbusto & CAA, CER, MAT, PAM \\
\hline Physalis angulata L.* & Moura \& Caires 06 (HVC) & NEN & Erva & Todos os domínios \\
\hline Physalis pubescens L. ${ }^{2}$ & HUESBVC7610 & NEN & Erva & Todos os domínios \\
\hline Schwenckia americana L. ${ }^{1,2}$ & Santos 2484 (CEPEC) & NEN & Erva & AMA, CAA, CER, MAT \\
\hline Schwenckia molissima Nees \& Mart. $^{1}$ & Torrend s.n. (ALCB03728) & NEN & Subarbusto & AMA, CAA, MAT \\
\hline Solanum agrarium Sendtn.* & Moura \& Caires 20 (HVC) & EN & Erva & CAA, CER, MAT \\
\hline Solanum americanum Mill. ${ }^{2}$ & Moura \& Caires 07 (HVC) & NEN & Erva & Todos os domínios \\
\hline Solanum asterophorum Mart. ${ }^{2}$ & HUESBVC7692 & EN & Arbusto & MAT \\
\hline Solanum crinitum Lam.* & Moura \& Caires 26 (HVC) & NEN & Arbusto & AMA, CAA, CER, MAT \\
\hline Solanum didymum Dunal ${ }^{1}$ & Mori 9476 (CEPEC) & NEN & Arbusto & AMA, CER, MAT \\
\hline Solanum flaccidum Vell. ${ }^{1}$ & Mori $9429(\mathrm{NY})$ & NEN & Liana & MAT, PAM \\
\hline Solanum gardneri Sendth. ${ }^{1}$ & Barbosa et al. 251 (HURB) & EN & Arbusto & CAA, MAT \\
\hline Solanum granulosoleprosum Dunal ${ }^{1}$ & Carvalho et al. 2598 (UB) & NEN & Árvore & CER, MAT, PAM \\
\hline Solanum mauritianum Scop. ${ }^{1}$ & Duarte 9299 (MBM) & NEN & Arbusto & MAT, PAM \\
\hline Solanum megalonyx Sendtn. ${ }^{1}$ & Schury 615 (US) & EN & Arbusto & AMA, CAA, CER \\
\hline Solanum palinacanthum Dunal ${ }^{2}$ & Moura \& Caires 22 (HVC) & NEN & Arbusto & Todos os domínios \\
\hline Solanum paniculatum L. ${ }^{2}$ & Moura \& Caires 28 (HVC) & NEN & Arbusto & Exceto Pantanal \\
\hline Solanum rhytidoandrum Sendtn.* & Moura \& Caires 30 (HVC) & NEN & Arbusto & AMA, CAA, CER \\
\hline Solanum robustum H.L.Wendl. ${ }^{1}$ & Scbury 618 (US) & NEN & Arbusto & MAT \\
\hline Solanum sisymbriifolium Lam.* & Moura \& Caires 19 (HVC) & NEN & Subarbusto & Todos os domínios \\
\hline Solanum stenandrum Sendtn. ${ }^{1}$ & Mori 15045 (CEPEC) & EN & Subarbusto & CAA, CER \\
\hline Solanum stipulaceum Willd. ex Roem. \& Schult. ${ }^{1,2}$ & Moura \& Caires 01 (HVC) & EN & Arbusto & CAA, CER, MAT \\
\hline Solanum thomasiifolium Sendtn. ${ }^{1,2}$ & Moura \& Caires 04 (HVC) & EN & Arbusto & CAA, CER, MAT \\
\hline Solanum viarum Dunal* & Moura \& Caires 09 (HVC) & NEN & Arbusto & Exceto Caatinga \\
\hline
\end{tabular}

\section{Brunfelsia obovata Benth., Prodr. [A.P. de Candolle] 1846;10:199.}

Figura 2a-j.

Arbusto $30 \mathrm{~cm}$ alt., ereto, inerme. Caules e ramos cilíndricos, glabros.

Folhas simples, discolores, subcoriáceas, lâmina 2,7-4,0 × 1,9-2,5 cm, obovada a elíptica, ápice agudo, base aguda, margem inteira, ciliada a puberulenta, face adaxial verde escuro, lisa, com nervura principal pubescente, com tricomas simples, face abaxial glabra, verde claro amarelado; pecíolo 0,2-0,5 $\mathrm{mm}$ de compr., cilíndrico, pubescente, com tricomas simples. Inflorescência cimeira terminal, pluriflora. Botões florais obovados. Flores hermafroditas, pediceladas, vistosas. Cálice tubular a campanulado, anguloso, tubo $0,8-1,1 \mathrm{~cm}$ de compr., inflado, verde claro, glabro, lacínias lanceoladas a triangulares, partida menos da metade do comprimento, com tricomas simples ou glandulares nas margens. Corola púrpura, passando a alva na senescência, hipocrateriforme, tubo da corola $1,0-1,7 \mathrm{~cm}$ de compr., lobos arredondados, revestido por tricomas esparsos glandulares, diminutos.
Anteras pardas, deiscência longitudinal. Estigma bífido, ovário cônico a ovoide. Frutos e sementes não observados.

Fenologia: coletada com flores em fevereiro.

Material examinado - BRASIL, Bahia: Vitória da Conquista, matinha da Universidade Estadual do Sudoeste da Bahia, 04/II/2020, Moura \& Caires 21 (HUESBVC, HVC).

Brunfelsia obovata é uma espécie endêmica do Brasil, está distribuída na região Nordeste (BA, PI), Centro-Oeste (DF, GO) e Sudeste (MG, RJ, SP), em áreas dos domínios fitogeográficos da Caatinga, Cerrado e Mata Atlântica (Flora do Brasil, 2020). Na Bahia, a espécie é pouco amostrada; há registros somente para as regiões oeste, sudoeste e sul do Estado (CRIA, 2020). Habita ambientes úmidos (Plowman, 1998; Ruszczyk; Nascimento, 1999). Na área em estudo, a espécie foi encontrada em borda de um fragmento florestal de mata-de-cipó. 
Figura 2. Brunfelsia obovata Benth. a: Hábito; b-c: Face adaxial e abaxial da folha; d: Detalhe da flor; e: Botões florais; f: Detalhe do botão e cálice; g: Corola em perfil; h: Antera com deiscência longitudinal; i: Tricomas glandulares no tubo da corola; j: Tricomas glandulares na borda do cálice.

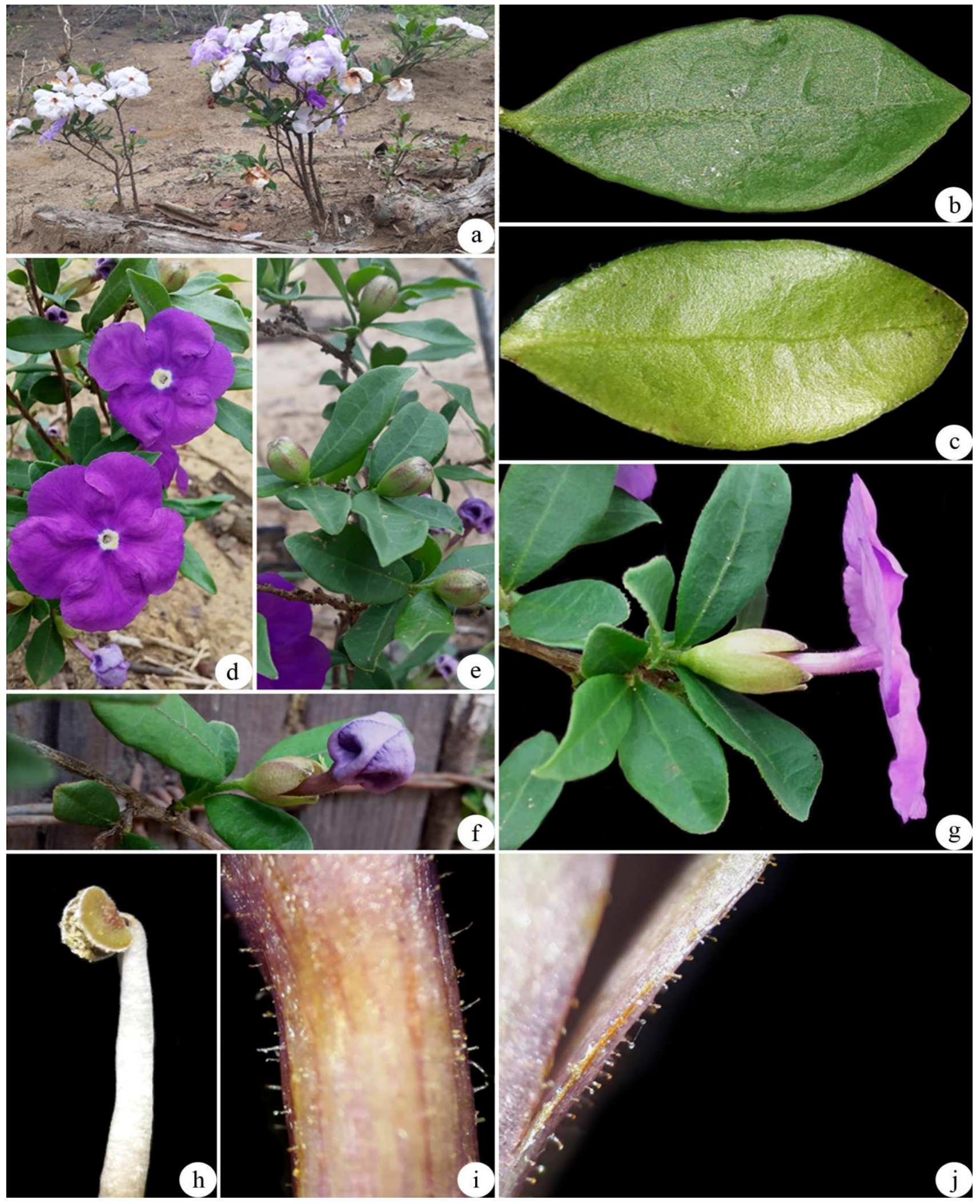


3. Capsicum baccatum L., Mant. Pl. 1767;1:47. Figura 3a-g.

Arbusto $40 \mathrm{~cm}$ alt., ereto, inerme. Caules e ramos cilíndricos, pubescentes, revestidos por tricomas simples. Folhas simples, solitárias, discolores, membranáceas, lâmina 3,6-5,0 × 2,5-3,2 cm, elíptica a ovada, base oblíqua, ápice cuspidado a acuminado, margem inteira, vilosa, ambas as faces glabras a pubescentes, com tricomas simples; pecíolo 0,7-1,2 cm de compr., cilíndrico. Inflorescência cimeira axilar, extra-axilar. Botões florais não observados. Flores hermafroditas, pediceladas. Cálice com borda truncada, lobos $0,4 \times$ $0,3 \mathrm{~mm}$, pubescentes, com tricomas simples, com cinco lacínias filiformes a aciculares, pubescentes. Corola $0,4-0,6 \mathrm{~cm}$ diâm., rotada, branca com manchas esverdeadas, pubescente, lacínias triangulares a agudas. Anteras amarelas, deiscência longitudinal. Ovário oblongo, estigma bilobado. Baga 0,6 × 1,0 cm, lisa, subglobosa a alongada, epicarpo alaranjado a vermelho na maturidade, cálice frutífero não envolvendo o fruto. Sementes numerosas, reniformes.

Fenologia: coletada com flores e frutos em fevereiro.

Material examinado - BRASIL, Bahia: Vitória da Conquista, curral próximo ao colégio CETEP, localizado no campus da Universidade Estadual do Sudoeste da Bahia, 20/II/2020, Moura \& Caires 25 (HUESBVC, HVC).

Capsicum baccatum é uma espécie que possui a América do Sul como centro de dispersão, é amplamente cultivada na Argentina, Colômbia, Equador, Peru, Bolívia e Brasil (Soares et al., 2008). No Brasil, a espécie ocorre no Nordeste (BA), Sudeste (ES, MG, RJ, SP), Sul (PR, RS, SC) e está presente nos domínios fitogeográficos do Cerrado, Mata Atlântica e Pantanal (Flora do Brasil, 2020). Na Bahia, a espécie é pouco amostrada, com alguns registros somente para o centro-norte, centro-leste e litoral sul do Estado (CRIA, 2020). É facilmente encontrada em clareiras, bordas de mata e locais antropizados. A espécie apresenta ampla importância econômica, visto que é cultivada em diversos lugares do mundo como uma especiaria ou hortaliça (Carvalho et al., 2006). Na área em estudo, a espécie foi encontrada em uma área de pastagem, em local úmido.

4. Cestrum axillare Vell., Fl. Flumin. 1829;101. Icone 1827;3: t. 6. Figura $4 \mathrm{a}-\mathrm{h}$.

Arvoreta, 2,30 $\mathrm{m}$ alt., inerme. Caules e ramos glabros a glabrescentes, com tricomas esparsos simples, pseudoestípulas elípticas presentes. Folhas simples, alternas, glabras, levemente discolores, papiráceas, lâmina 4,4-8,5 $\times 2,2-3,5 \mathrm{~cm}$, elípticolanceolada ou oblonga, ápice agudo, base obtuso-acunheada, margem inteira a ondulada, ambas as faces glabras, face adaxial verde, face abaxial verde claro; pecíolo 0,4-1,2 cm de compr., cilíndrico, glabro. Inflorescência em cimeiras, plurifloras, axilares ou terminais, panículas, pubescentes, tricomas simples. Botões florais não observados. Flores hermafroditas, sésseis ou apresentando um pedicelo curto. Cálice $0,6 \times 0,3 \mathrm{~mm}$, tubuloso, pubescente, revestido por tricomas simples, lobos triangulares a dentados, hipsofilo $0,7 \times$ $0,3 \mathrm{~mm}$. Corola branco-arroxeada a creme-esverdeada, hipocrateriforme, tubo $1,7-2,5 \mathrm{~cm}$ de compr., glabrescente, lobos triangulares a lanceolados. Anteras amarelo-ouro, deiscência longitudinal. Estigma capitado ou lobado, ovário subgloboso. Baga $1,4 \times 0,8 \mathrm{~cm}$, ovoide, alongada, glabra, verde quando jovem, roxonigrescente na maturidade, cálice frutífero não envolvendo o fruto. Sementes não observadas.

Fenologia: coletada com flores e frutos maduros em fevereiro.

Material examinado - BRASIL, Bahia: Vitória da Conquista, próximo à comunidade Santa Marta, na margem do rio Verruga, 20/II/2020, Moura \& Caires 23 (HUESBVC, HVC).

Cestrum axillare é uma espécie que apresenta ampla distribuição no Brasil, havendo registros para as regiões Norte (AC, AM), Nordeste (AL, BA, CE, MA, PB, PE, RN, SE), Centro-Oeste (DF, GO, MS, MT), Sudeste (ES, MG, RJ, SP) e Sul (PR, SC), abrangendo os domínios fitogeográficos da Mata Atlântica, Cerrado, Pantanal, Caatinga e Amazônia (Flora do Brasil, 2020). A espécie ocorre em especial nas regiões Sudeste e Centro-Oeste, em regiões litorâneas do Nordeste, como na Bahia, em Sergipe, Alagoas e Pernambuco. Para a Bahia, há uma maior distribuição para o centro-norte, centro-leste, leste, sul e porções da região sudoeste do Estado (CRIA, 2020).

É considerada uma planta hepatotóxica, portanto, causa necrose hepática em espécies bovinas. No estado da Bahia é frequentemente utilizada para sombreamento nas plantações de cacau. Coloniza margens de estradas, bordas de fragmentos em que haja cursos de água e restingas das regiões tropicais do país (Marinho et al., 2018). Na área em estudo, a espécie foi encontrada na margem do rio Verruga em solo úmido.

\section{Datura stramonium L., Sp. Pl. 1753;1:179. Figura 5a-h.}

Arbusto $45 \mathrm{~cm}$ alt., ereto, inerme. Caules e ramos cilíndricos a levemente sulcados, glabros a pubescentes, com tricomas simples. Folhas simples, alternas, discolores, membranáceas a subcoriáceas, lâmina 7,6-12,6 × 5,0-6,9 cm, oval a elíptica, ápice acuminado, base oblíqua, margem dentada, face adaxial pubescente, com tricomas simples, nervuras bem desenvolvidas, ambas as faces pubescentes quando jovens, com tricomas esparsos simples, glabras na maturidade, face adaxial verde escura, face abaxial verde claro; pecíolo $0,8-1,8 \mathrm{~cm}$ de compr., glabro. Inflorescência solitária, extra-axilar. Botões florais ovoides a oblongos. Flores hermafroditas, pediceladas. Cálice 2,7 $\times 1,3 \mathrm{~cm}$, tubular, anguloso, verde claro, circunciso, lacínias triangulares. Corola branca, tubular, tubo $5,0-7,5 \mathrm{~cm}$ de compr., com seis apêndices filiformes. Anteras alvas a cremes, deiscência longitudinal. Estigma globoso, ovário 0,3-0,2 mm, subgloboso, espinescente. Cápsula $4,1 \times 3,3 \mathrm{~cm}$, espinescente, epicarpo verde quando jovem e pardo na maturidade, cálice frutífero não envolvendo o fruto. Sementes não observadas.

Fenologia: coletada com flores e frutos imaturos em fevereiro e agosto.

Material examinado - BRASIL, Bahia: Vitória da Conquista, curral próximo ao colégio CETEP, 20/XIII/2019, Moura \& Caires 8 (HUESBVC, HVC); próximo à comunidade Santa Marta, 20/II/2020, Moura \& Caires 24 (HUESBVC, HVC). 
Figura 3. Capsicum baccatum L. a: Hábito. b-c: Face adaxial e abaxial da folha; d: Margem foliar ciliada; e: Detalhe da flor; f: Cálice truncado com lacínias filiformes; g: Frutos.

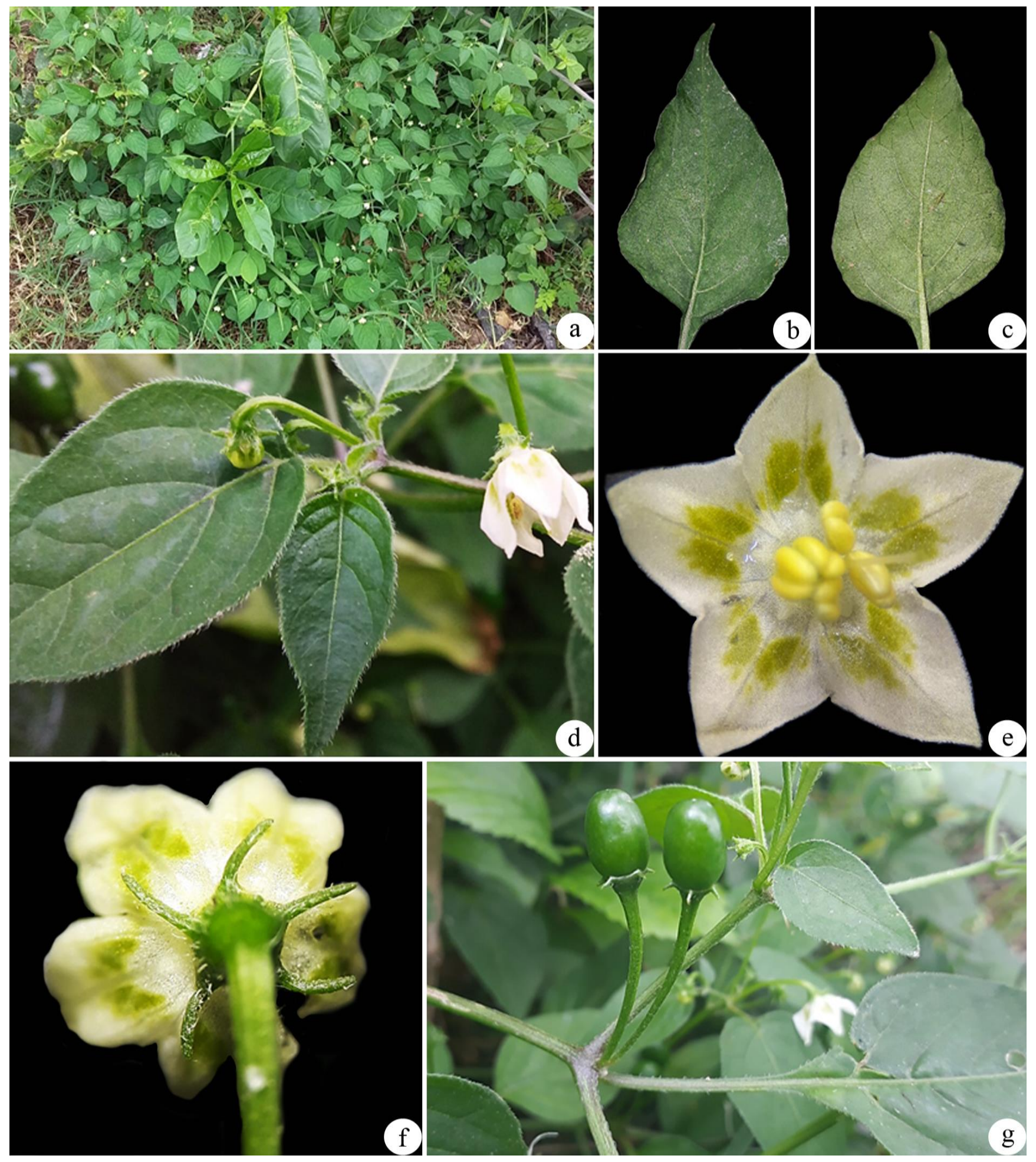


Figura 4. Cestrum axillare Vell. a: Hábito; b-c: Face adaxial e abaxial da folha; d: Detalhe da corola; e: Inflorescência; f: hipsofilo g: pseudoestípulas; h: Frutos maduros.
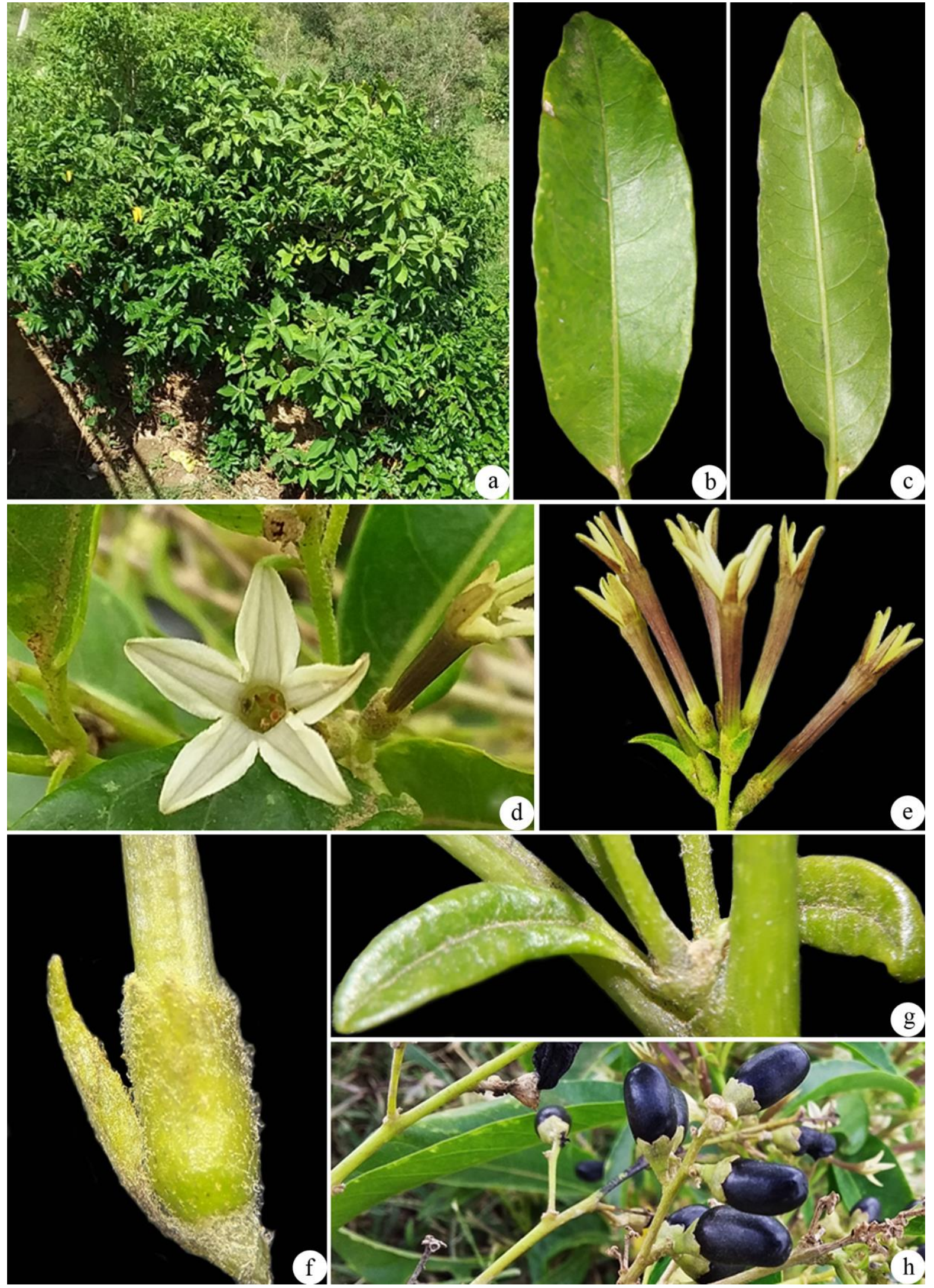
Figura 5. Datura stramonium L. a: Hábito; b-c: Face adaxial e abaxial da folha; d: Detalhe da corola; e: Botão floral; f: Secção transversal do ovário; g: Tricomas simples da face adaxial da folha; h: Cápsula espinescente.
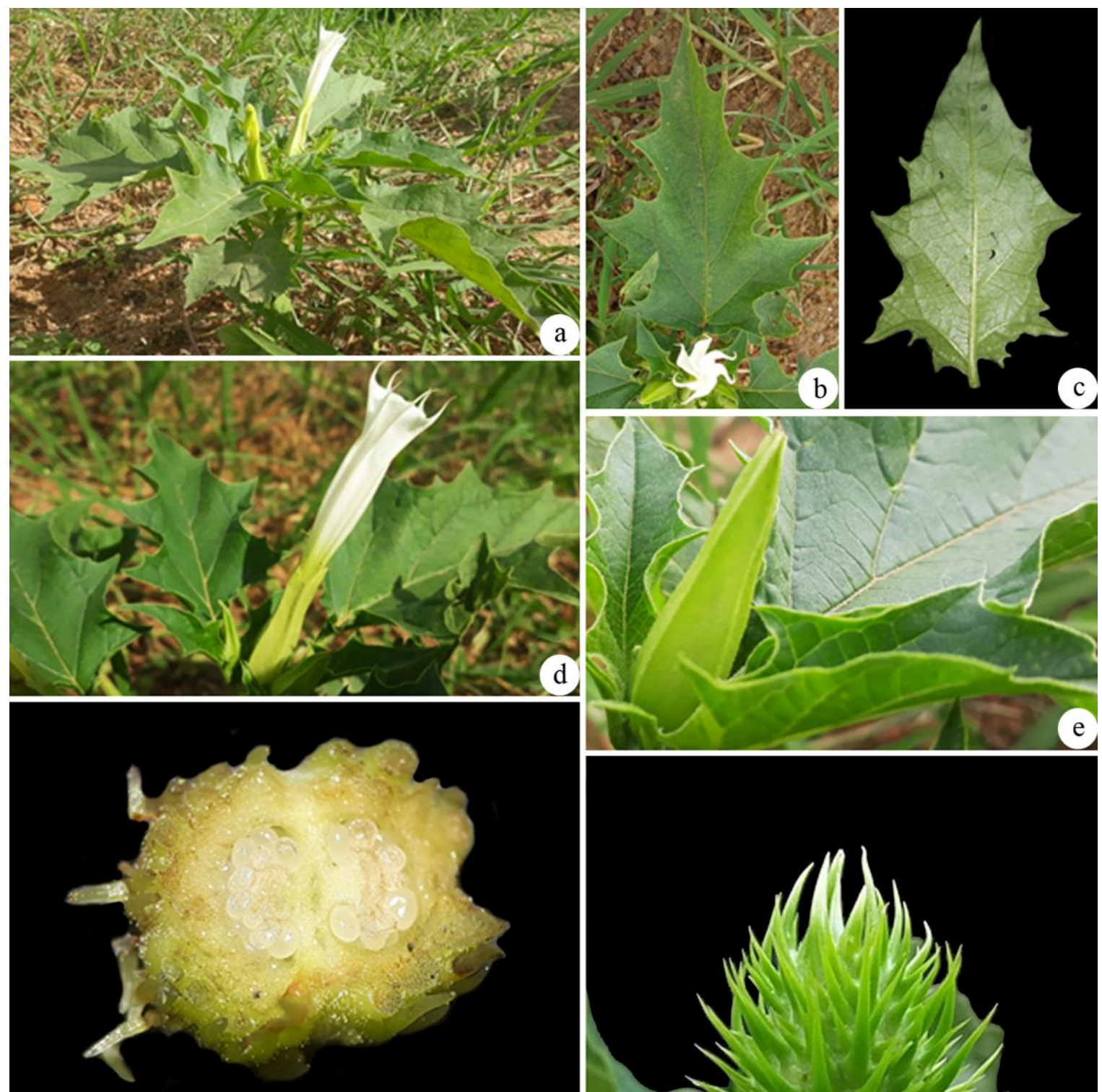

(f)
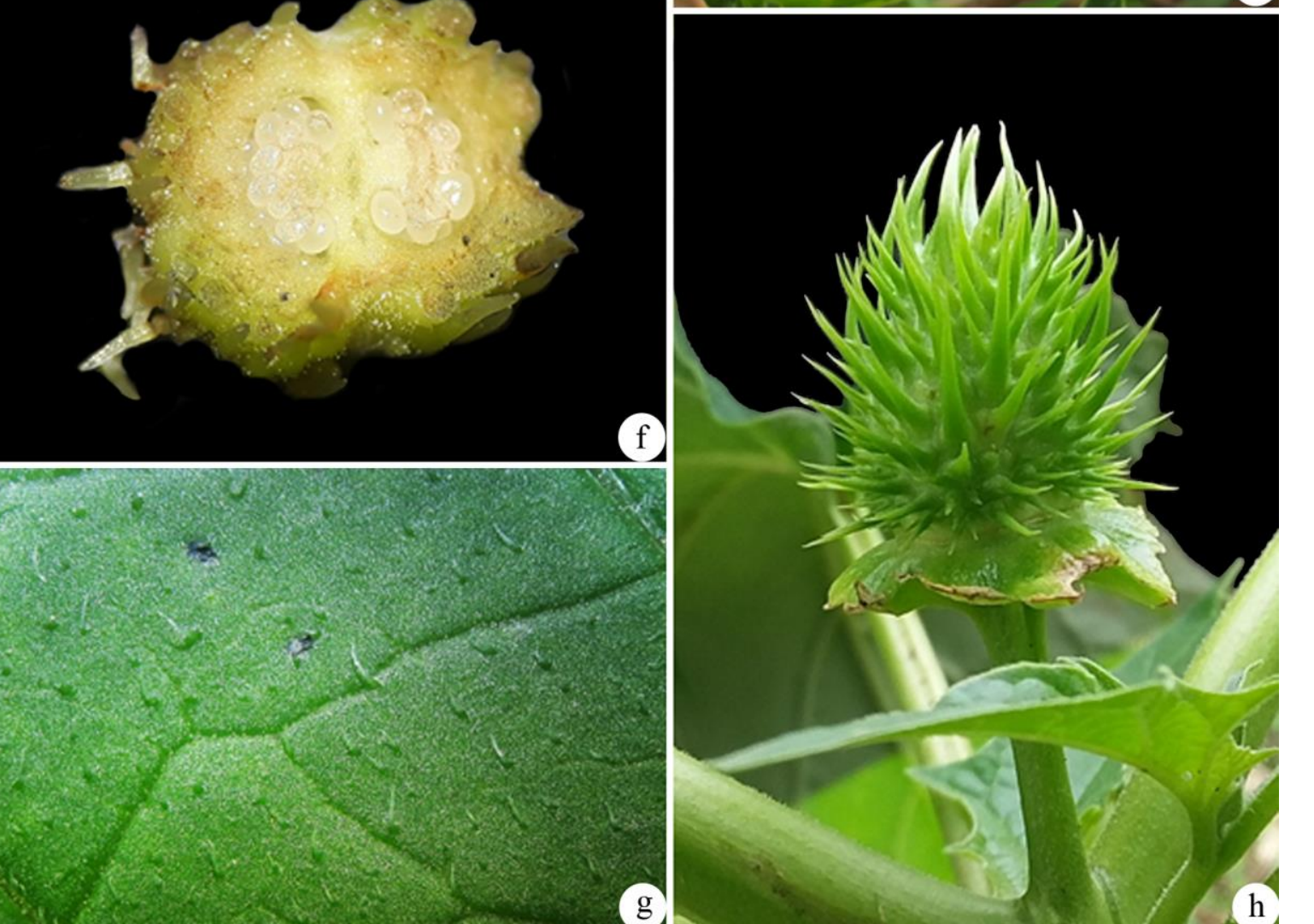

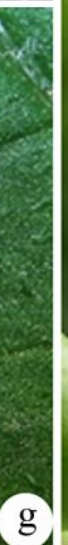

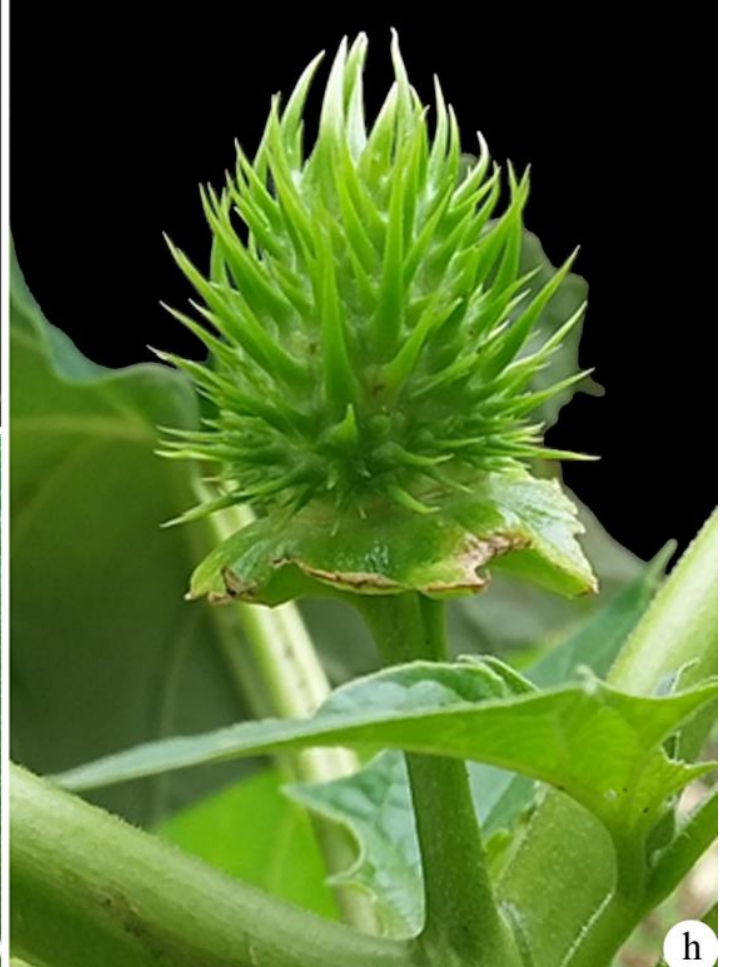


Datura stramonium, assim como as demais espécies do gênero, é nativa das Américas, sendo o México seu principal centro de diversidade (Luna-Cavazos; Bye, 2011). Atualmente é considerada cosmopolita após sua introdução pelos europeus em diversas partes do mundo (Luna-Cavazos; Bye, 2011; Al-Snafi, 2017). No Brasil, possui ocorrências nas regiões Nordeste (AL, BA, CE, PB, PE, PI, RN, SE), Centro-Oeste (DF, GO), Sudeste (SP) e Sul (RS, SC), em domínios fitogeográficos da Caatinga, Cerrado e Mata Atlântica (Flora do Brasil, 2020). Na Bahia, a espécie é pouco amostrada, com alguns registros para as regiões leste, centro-leste e sudoeste do Estado.

A espécie é conhecida popularmente como figueira-do-inferno ou cálice-de-vênus, sendo considerada uma solanácea invasora de caráter tóxico, em razão das substâncias constituintes com efeitos alucinógenos e eufóricos (Soni et al., 2012). Entretanto, na medicina popular, pode ser utilizada no tratamento de enfermidades como úlceras, feridas e inflamações (Soni et al., 2012). No presente estudo a espécie foi encontrada em uma área de pastagem em local úmido e também próximo a curso de água.

6. Iochroma arborescens (L.) J.M.H. Shaw, Plantsman 2018;17(3): 200. Figura 6a-f.

Arvoreta $2 \mathrm{~m}$ alt., ereta, inerme. Caules e ramos cilíndricos, glabrescentes. Folhas simples, discolores, lâmina 5,0-14,0 × 2,9-7,3 $\mathrm{cm}$, membranácea, ovada a lanceolada, ápice agudo, base atenuada, margem inteira a ondulada, face adaxial, revestida por tricomas simples, em especial nas nervuras foliares, face abaxial, com tricomas simples; pecíolo $1,0-2,8 \mathrm{~cm}$ de compr., cilíndrico, pubescentes. Inflorescência pluriflora, fasciculada a glomeruliforme, com tricomas simples. Botões florais não observados. Flores pediceladas com tricomas simples, hermafroditas. Cálice campanulado, tubo 0,4-0,6 $\mathrm{mm}$ de compr., glabrescente com tricomas simples, lacínias triangulares a lanceoladas.

Corola 2,1 $\times 0,6 \mathrm{~cm}$, campanulada, alva a creme com manchas esverdeadas, pétalas soldadas na maior parte do seu comprimento, lobos revolutos. Anteras amarelas, oblongas, deiscência longitudinal. Estigma capitado, ovário ovoide. Baga 1,0 $\times 0,9 \mathrm{~cm}$, globosa, epicarpo glabro, verde quando jovem, alaranjado na maturidade, cálice frutífero não acrescente. Sementes numerosas, discoides.

Fenologia: Coletada com flores e frutos maduros em fevereiro e dezembro.

Material examinado - BRASIL, Bahia: Vitória da Conquista, Avenida Iolando Fonseca, próximo ao Samu, 6/XII/2019, Moura \& Caires 18 (HUESBVC, HVC); próximo ao Residencial Palmira Bittencourt - Bairro Candeias, 13/II/2020, Moura \& Caires 29 (HUESBVC, HVC).

Iochroma arborescens pode ser encontrada no sul do México, na América Central, nas Antilhas e na América do Sul, em especial em margens de fragmentos florestais e clareiras (Verçoza et al., 2012). No Brasil, possui ocorrências nas regiões Sul (RS, SC), Sudeste (RJ, SP, MG) e Nordeste (BA, CE, PE) (Flora do Brasil, 2020), sendo popularmente conhecida como fruta-de-sabiá (Verçoza et al., 2012).
$\mathrm{Na}$ Bahia, a espécie ainda é pouca amostrada, sua distribuição concentra-se mais ao sul do Estado (CRIA, 2020).

Possui grande plasticidade de adaptação ao ambiente e, portanto, é considerada uma espécie muito importante para restauração de ambientes degradados, tendo em vista que atrai muitos polinizadores e dispersores devido às atrativas flores e aos vistosos frutos (Verçoza et al., 2012). Estudos farmacológicos apontam a existência de princípios ativos anticancerígenos na planta (Carvalho et al., 2001; Verçoza et al., 2012). Na área em estudo a espécie foi encontrada em margens de estradas, em fragmentos antropizados e em local próximo a curso de água.

7. Nicandra physalodes (L.) Gaertn., Fruct. Sem. Pl. 1791;2:237, t. 131, f. 2. Figura 7a-g.

Arbusto $45 \mathrm{~cm}$ alt., ereto, inerme. Caules e ramos sulcados, glabros a pubescentes, com tricomas simples e glandulares. Folhas simples, discolores, membranáceas, lâmina 5,5-12,8 × 4,3-8,7 cm, ovada a elíptica, ápice acuminado, base atenuada, margem dentada, ambas as faces com tricomas simples ou glandulares; pecíolo 1,2-3,4 cm de compr., cilíndrico, sulcado, glabro a pubescente. Inflorescência solitária, axilar, pedunculada. Botões florais não observados. Flores hermafroditas, pediceladas, pétalas soldadas na maior parte do seu comprimento. Cálice 1,8 × 1,6 cm, campanulado, lobos auriculados, ápice cuspidado, livre na maior do seu comprimento. Corola lilás a alva, campanulada, tubo 0,8-1,6 cm de compr., lacínias ovais. Anteras amarelo-pálidas, deltoides, deiscência longitudinal. Estigma capitado, ovário cônico ovoide, tetralocular. Baga 1,7 × 1,6 cm, globosa, coberta pelo cálice acrescente, epicarpo verde quando jovem, pardo a marrom na maturidade. Sementes não observadas.

Fenologia: Coletada com flores e frutos em agosto e setembro.

Material examinado - BRASIL, Bahia: Vitória da Conquista, curral próximo ao colégio CETEP, localizado no campus da Universidade Estadual do Sudoeste da Bahia, 20/VIII/2019, Moura \& Caires 5 (HUESBVC, HVC); Bairro Primavera, 14/IX/2019 Moura \& Caires 10 (HUESBVC, HVC).

Nicandra physalodes é originária da América do Sul, nativa do Peru e conhecida popularmente como joá-de-capote ou lanterna-da-china (Wang et al., 2017). No Brasil, a espécie se distribui pelas regiões Norte (PA), Nordeste (AL, BA, CE, PB, PE, SE), Centro-Oeste (DF, GO, MS), Sudeste (ES, MG, RJ, SP) e Sul (PR, SC), em domínios fitogeográficos da Caatinga, Cerrado e Mata Atlântica (Flora do Brasil, 2020). Na Bahia, a espécie é pouco amostrada, com registros apenas em regiões do centro-norte, leste e sul do Estado.

Trata-se de uma espécie que frequentemente coloniza locais férteis e úmidos, incluindo áreas agrícolas, onde causa sombreamento, prejudicando algumas culturas. Possui potencial medicinal e estudos da medicina tradicional chinesa apontam diversas propriedades, como sedativas e expectorantes (Silva; Agra, 2005; Wang et al., 2017). Na área em estudo, a espécie foi encontrada em pastagem e em terrenos baldios. 
Figura 6. Iochroma arborescens (L.) J.M.H.Shaw. a: Hábito; b: Face adaxial da folha; c: Inflorescências; d: Detalhe da flor; e: Antera com deiscência longitudinal; f: Frutos maduros.
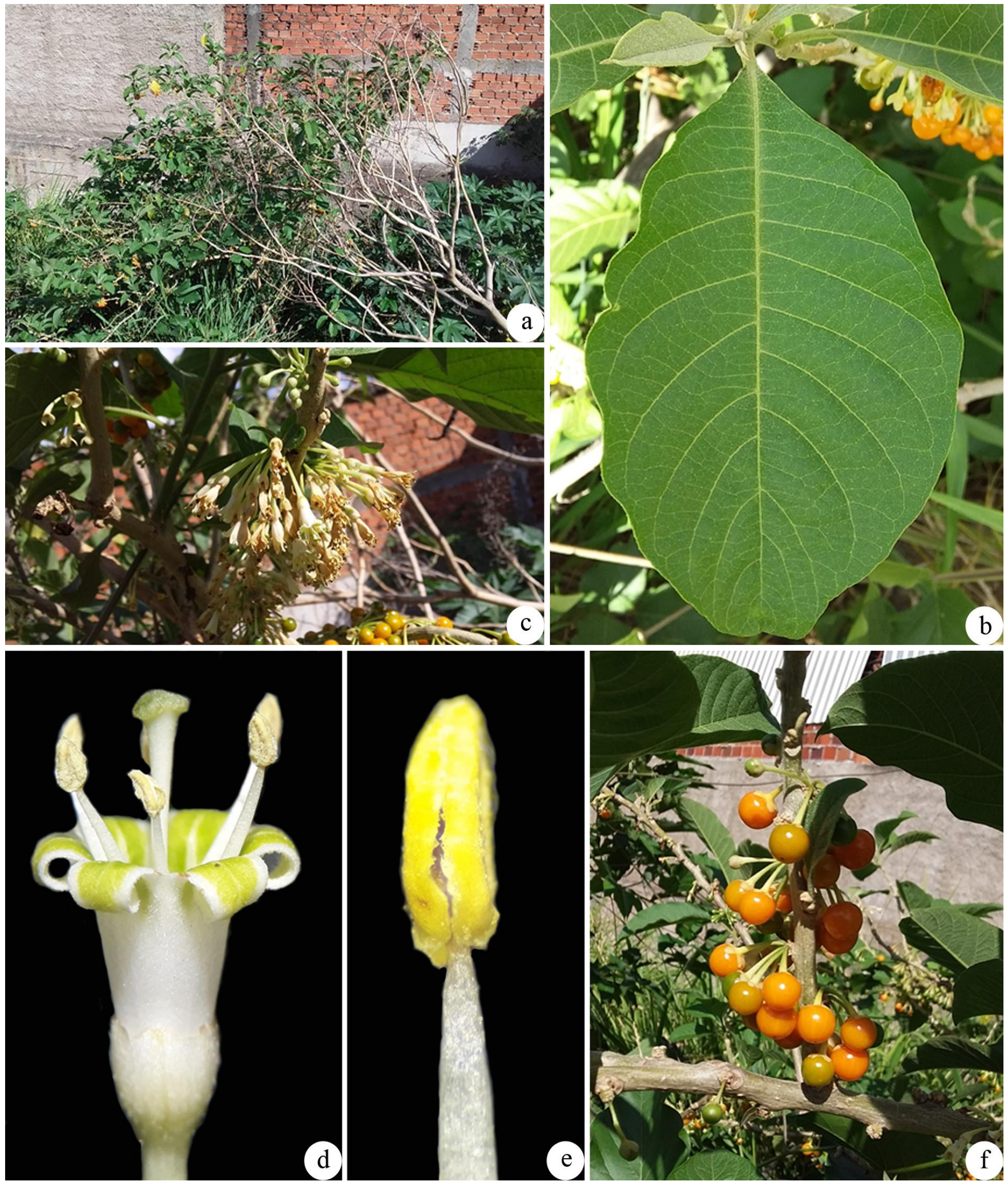
Figura 7. Nicandra physalodes (L.) Gaertn. a: Hábito; b: Corola em vista frontal; c: Detalhe do cálice frutífero acrescente; d: Fruto imaturo; e: Anteras com deiscência longitudinal; f: Cálice frutífero; g: Fruto maduro.
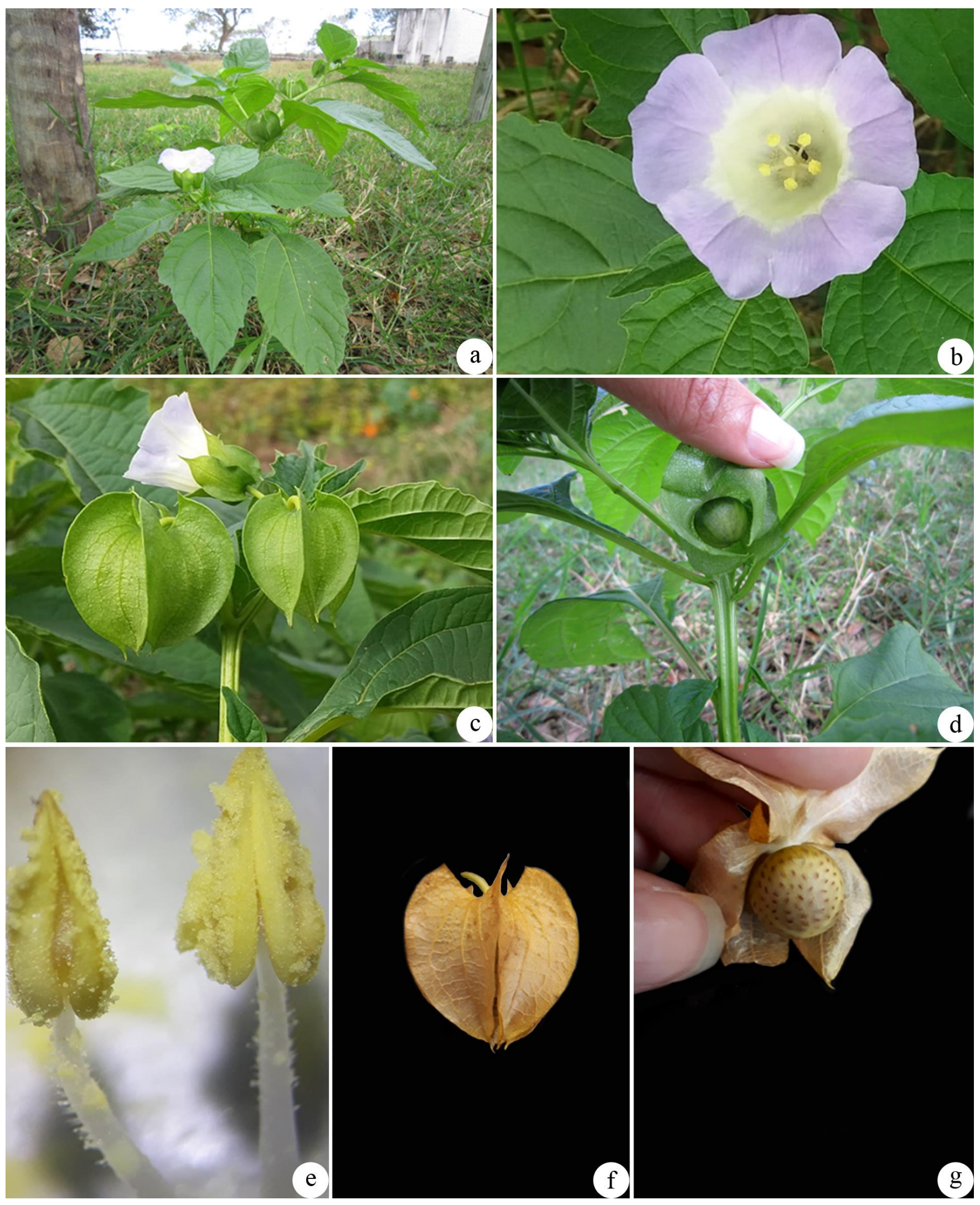
8. Nicotiana glauca Graham, Bot. Mag. 1828;55(2/2): t. 2837. Figura 8a-e.

Arvoreta $5 \mathrm{~m}$ alt., ereta, inerme. Caules e ramos cilíndricos, glabros. Folhas simples, concolores, membranáceas a subcoriáceas, lâmina $5,5-7,7 \times 3,1-4,2 \mathrm{~cm}$, elíptica a lanceolada, ápice cuspidado, base obtusa, margem inteira, ambas as faces glabras, verde cinéreo; pecíolo, 1,1-3,2 cm de compr. Inflorescências terminais, plurifloras, glabras. Botões florais não observados. Flores pediceladas, hermafroditas. Cálice $1,5 \times 0,7 \mathrm{~cm}$, campanulado a tubuloso, glabro, lobos acuminados. Corola amarelo-esverdeada, tubulosa, constrita na região apical, tubo 2,6-3,3 $\times 0,6-0,9 \mathrm{~cm}$, pubescente, revestida por tricomas simples na face externa, lobos agudos; anteras pardas a amarelas, deiscência longitudinal. Estigma bilobado, ovário oval. Cápsula 2,0 $\times 1,3 \mathrm{~cm}$, elipsoide, glabra, verde quando jovem, marrom na maturidade, cálice envolvendo o fruto. Sementes marrons, numerosas, sub-reniformes.

Fenologia: Coletada com flores e frutos em agosto e novembro.

Material examinado - BRASIL, Bahia: Vitória da Conquista, margem da estrada da Barra, próximo ao anel viário da avenida Rosa Cruz, 08/VIII/2019, Moura \& Caires 2 (HUESBVC, HVC); fundo do condomínio Alphaville, próx. à guarita da Universidade Estadual do Sudoeste da Bahia, 19/XI/2019, Moura \& Caires 16 (HUESBVC, HVC).

Nicotiana glauca é uma espécie nativa da América do Sul e encontrase distribuída em zonas áridas e semiáridas do mundo, como na Arábia Saudita, Chile, Estados Unidos e México (Fabricante et al., 2015). A espécie pode ser encontrada ainda na Austrália, Croácia, Espanha, Namíbia e Portugal (Silva et al., 2007; Fabricante et al., 2015). No Brasil, a espécie distribui-se pelas regiões Nordeste (AL, BA, CE, PB, PE, PI, RN, SE), Centro-Oeste (DF, GO, MS), Sudeste (ES, MG, RJ, $\mathrm{SP})$ e Sul (PR, RS, SC), em domínios fitogeográficos da Caatinga, Cerrado e Mata Atlântica (Flora do Brasil, 2020). Na Bahia, a espécie está em maior abundância nas regiões norte, centro-norte e sudoeste do Estado (CRIA, 2020).

É considerada uma planta invasora, podendo ser encontrada em ambientes úmidos, ruderais e bordas de estradas. Apresenta toxicidade tanto para animais quanto para humanos, em virtude da presença de princípios ativos, como o alcaloide anabasina (Fabricante et al., 2015). Indivíduos de Nicotiana glauca possuem grande habilidade de produzir e dispersar propágulos, podendo variar de 10.000-1.000.000 de propágulos por indivíduo (Fabricante et al., 2015). Na área em estudo, a espécie foi encontrada em margens de estradas e em terrenos baldios, sempre em pequenas populações.

\section{Physalis angulata L., Sp. Pl. 1753;1:183.}

Erva $24 \mathrm{~cm}$ alt., ereta, inerme. Caules e ramos angulosos, glabros a pubescentes, com tricomas esparsos, simples. Folhas alternas, simples, discolores, membranáceas, lâmina 4,5-8,8 $\times 3,5-7,1 \mathrm{~cm}$, ovada a elíptica, ápice acuminado, base oblíqua, margem dentada ou levemente lobada, ambas as faces com tricomas glabrescentes; pecíolo $0,3-3,5 \mathrm{~cm}$ de compr., anguloso. Inflorescência axilar, uniflora. Botões florais não observados. Flores hermafroditas, com pedicelo cilíndrico, pubescente. Cálice $0,5 \times 0,4 \mathrm{~mm}$, campanulado, sépalas soldadas na maior parte do seu comprimento. Corola rotáceocampanulada, amarelo-pálida, tubo 0,8-0,9 mm de compr., com máculas marrons no interior do tubo, lacínias triangulares. Anteras azuis, deiscência longitudinal. Estigma capitado, ovário subgloboso. Baga 1,6 × 1,5 cm, globosa envolvida pelo cálice acrescente e inflado, epicarpo verde quando jovem. Sementes não observadas.

Fenologia: Coletada com flores e frutos imaturos em agosto.

Material examinado - BRASIL, Bahia: Vitória da Conquista, curral próximo ao colégio CETEP localizado no campus da Universidade Estadual do Sudoeste da Bahia, 20/VIII/2019, Moura \& Caires 6 (HUESBVC, HVC).

Physalis angulata é uma espécie que ocorre abundantemente na América Central, América do Sul e em parte da América do Norte, como nos Estados Unidos (Soares et al., 2009). No Brasil, ocorre em quase todos os estados, exceto em Roraima, Tocantins e Sergipe, assim como ocorre em todos os domínios fitogeográficos, exceto no Pampa (Flora do Brasil, 2020). Para a Bahia, há uma maior distribuição nas regiões centro-leste, leste e litoral sul baiano (CRIA, 2020). É considerada uma erva daninha que habita preferencialmente ambientes antropizados, ruderais e terrenos baldios. Possui propriedades anti-inflamatória, anti-diabética, além de outras, razão pela qual é amplamente utilizada na medicina popular (Silva; Agra, 2005). Na área em estudo, a espécie foi encontrada em uma pastagem, em local úmido.

10. Solanum agrarium Sendtn., Fl. Bras. [Martius] 1846;10:69. Figura $9 \mathrm{a}-\mathrm{h}$.

Erva ou subarbusto, ereta, $20 \mathrm{~cm}$ alt., aculeada. Caules e ramos cilíndricos, pubescentes, com tricomas simples, estrelados sésseis ou glandulares, acúleos $0,2-0,8 \mathrm{~mm}$ de compr., aciculares, unidade simpodial difoliada. Folhas simples, alternas, discolores, aculeadas, acúleos cônicos, membranáceas a coriáceas, lâmina 2,8-5,9 × 1,6-3,9 $\mathrm{cm}$, ovado-elíptica, ápice agudo, base sub-cordada, margem lobada, face adaxial pubescente, tomentosa, com tricomas simples, glandulares, face abaxial com tricomas estrelados, sésseis; pecíolo 0,9-2,5 cm de compr., cilíndrico. Inflorescência em cimeira, extraaxilar. Botões florais ovoides. Flores hermafroditas, pediceladas. Cálice 0,5 $\times 0,4 \mathrm{~mm}$, campanulado, piloso, levemente aculeado, acúleos cônicos a aciculares, lobos triangulares a agudos. Corola 1,7 $\times 2,3 \mathrm{~cm}$ de diâm., estrelada, esverdeada, lobos triangulares, revolutos. Anteras verdes, lanceoladas, deiscência longitudinal. Ovário globoso. Baga 1,8 $\times 1,3 \mathrm{~cm}$, globosa, não envolvida pelo cálice frutífero, epicarpo verde claro, pubescente. Sementes não observadas.

Fenologia: Coleta com flores e frutos imaturos em janeiro.

Material examinado - BRASIL, Bahia: Vitória da Conquista, Avenida Eduardo Campos, 23/I/2020, Moura \& Caires 20 (HUESBVC, HVC). 
Figura 8. Nicotiana glauca Graham. a: Hábito; b. Inflorescência; c: Detalhe da flor; d: Antera com deiscência longitudinal; e: Frutos maduros.

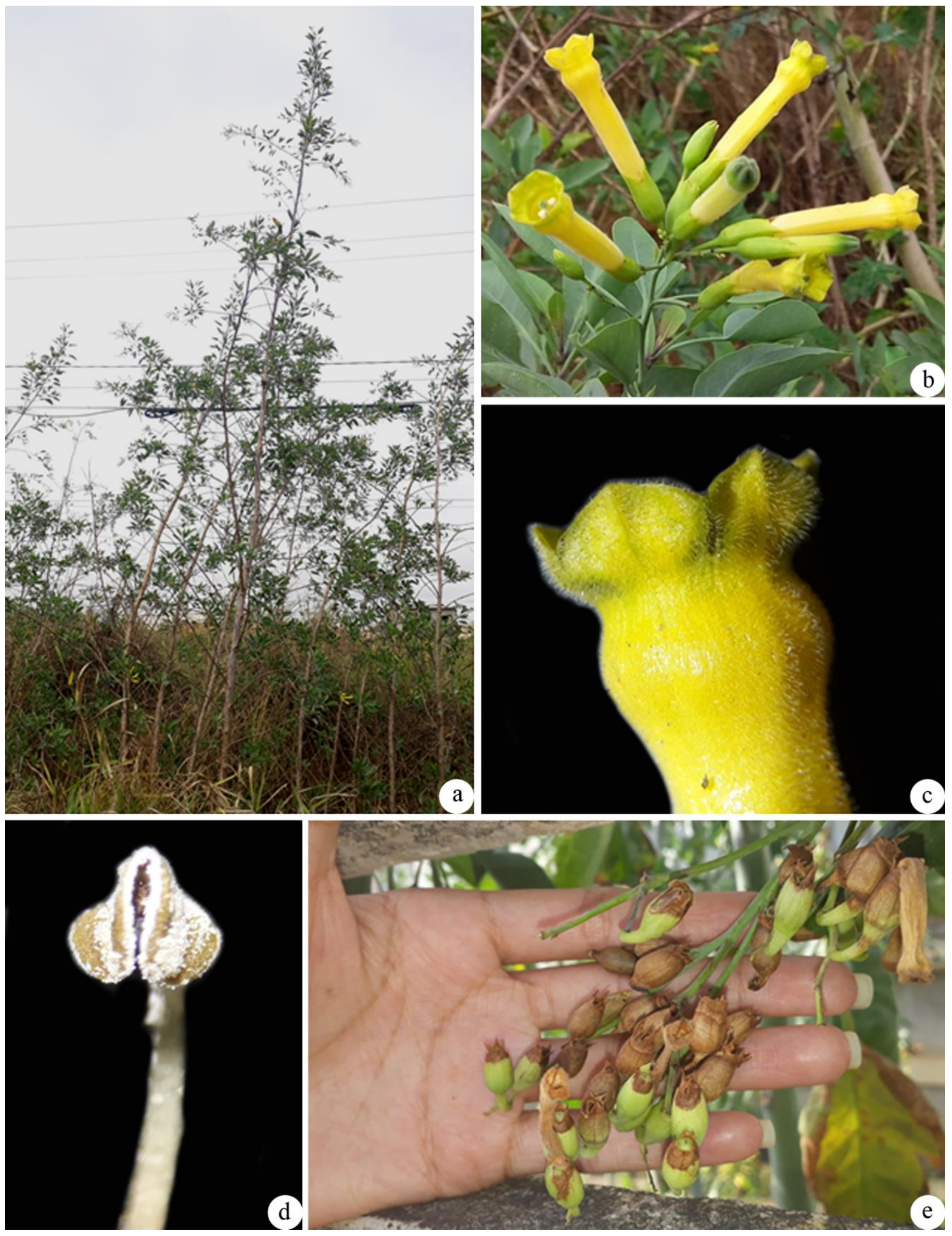


Figura 9. Solanum agrarium Sendtn. a: Hábito; b-c: Face adaxial e abaxial da folha; d-e: Detalhe da flor e anteras; f: Inflorescência; g: Tricoma séssil estrelado da face abaxial da folha; h: Fruto.
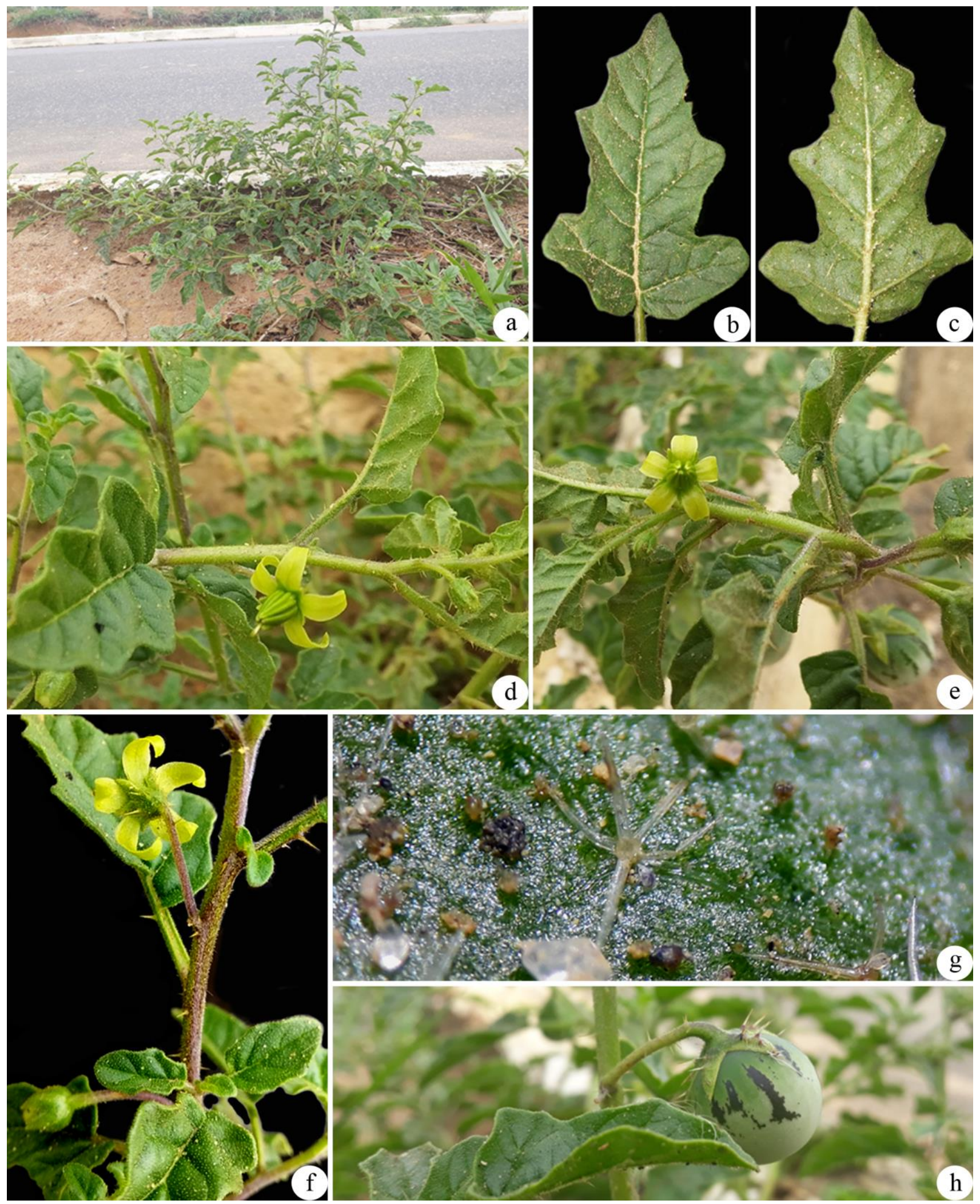
Solanum agrarium é uma espécie que pode ser encontrada na Colômbia, Venezuela, Antilhas Holandesas e Caribe, em ambientes quentes e secos (Agra et al., 2009). No Brasil, S. agrarium ocorre nas regiões Norte (TO), Centro-Oeste (GO) e Sudeste (MG) e em todos os estados da região Nordeste (Flora do Brasil, 2020). Para a Bahia, a espécie distribui-se em partes do norte, centro-norte, centro-leste e sudoeste do Estado (CRIA, 2020). Habita áreas antropizadas, restingas e bordas de florestas. Conforme estudos de Matias et al. (2019), a espécie apresenta metabólitos eficientes na atividade medicinal, podendo agir como diurético e antisséptico, atuando como enzimas reguladoras. $\mathrm{Na}$ área estudada, o espécime foi encontrado em uma margem de estrada, como o único exemplar do local.

11. Solanum americanum Mill., Gard. Dict. 1768; ed. 8: 5. Figura 10a-f.

Erva ereta, $40 \mathrm{~cm}$ alt., inerme. Caules e ramos cilíndricos, glabros a pubescentes, com tricomas simples; unidade simpodial difoliada. Folhas simples, concolores, membranáceas, lâmina 3,7-6,9 × 2,9-4,5 $\mathrm{cm}$, oval a elíptica, ápice agudo, base atenuada, ambas as faces glabras a pubescentes, com tricomas diminutos, simples esparsos; pecíolo 0,3-1,4 cm de compr., cilíndrico. Inflorescência simples, lateral, umbeliforme. Botões florais globosos a elipsoides. Flores hermafroditas, pediceladas. Cálice campanulado, tubo 0,1-0,2 $\mathrm{mm}$ de compr., lobos diminutos, agudos. Corola $0,5 \times 0,4 \mathrm{~cm}$, branca, pubescente, estrelada, partida mais da metade do seu comprimento, lobos deltoides a lanceolados. Anteras amarelas, oblongas, deiscência poricida abrindo-se em fendas. Estigma globoso, ovário subgloboso, pubescente. Baga $0,5 \times 0,5 \mathrm{~mm}$, globosa, não envolvida pelo cálice frutífero, epicarpo glabro, verde quando jovem e negro na maturidade. Sementes não observadas.

Fenologia: coletada com flores e frutos maduros em agosto.

Material examinado - BRASIL, Bahia: Vitória da Conquista, curral próximo ao colégio CETEP, localizado na Universidade Estadual do Sudoeste da Bahia, 20/VIII/2019, Moura \& Caires 7 (HUESBVC, HVC).

Solanum americanum possui ampla distribuição mundial, ocorre em toda a América, desde os EUA até a Argentina e o Chile (Giacomin; Gomes, 2018). No Brasil, possui distribuição ampla, ocorrendo em toda extensão do território brasileiro, bem como em todos os domínios fitogeográficos (Flora do Brasil, 2020). Para a Bahia, a espécie é bem amostrada para o litoral sul, leste e centro-leste do Estado (CRIA, 2020). É uma espécie frequente em ambientes úmidos, sombreados, fragmentos antropizados e clareiras (Moreira; Bragança, 2011). É considerada uma das principais espécie invasoras nas culturas comerciais no Brasil (Parreira et al., 2010). Na área em estudo, a espécie foi encontrada em uma pastagem, em local úmido.

12. Solanum crinitum Lam., Tab. Encycl. 1794;2:20. Figura 11a-h.

Arbusto ca. 2,0 m alt., ereto, fortemente aculeado, acúleos 1,0-2,0 $\mathrm{cm}$ de compr., aciculares a cônicos. Caules e ramos tomentosos, com indumento ferrugíneo, apresentando tricomas porrecto-estrelados, curto e longo estipitado; unidade simpodial difoliada. Folhas simples, discolores, coriáceas, lâmina 7,0-16,6 × 6,5-12,4 cm, ovadas a elípticas, ápice agudo, base cordiforme a oblíqua, margem lobada, com acúleos cônicos ao longo da nervura principal, ambas as faces velutinas, tomentosas, com tricomas porrecto estrelados, sésseis, curto e longo estipitados, face abaxial mais tomentosa, tricomas porrectoestrelados; pecíolo 2,0-3,5 cm de compr., cilíndrico. Inflorescência simples, escorpioide, extra-axilar, densamente tomentosa. Botões florais oblongos. Flores hermafroditas, pediceladas. Cálice 3,2 × 2,9 $\mathrm{cm}$, campanulado, oblongo, densamente tomentoso, com tricomas estrelados, aculeado, lobos largo-lanceolados. Corola 4,5-5,0 cm de diâm., púrpura, rotácea, partida menos da metade do seu comprimento, lobos triangulares a deltoides. Anteras amarelas, lanceoladas, pilosas, deiscência poricida. Estigma capitado, ovário subgloboso. Baga 5,0 × 4,7 cm, globosa, epicarpo castanho, velutino, tomentoso, com tricomas porrecto-estrelados, cálice frutífero não acrescente. Sementes numerosas, ovadas.

Fenologia: Coletada com flores em novembro e frutos imaturos em fevereiro.

Material examinado - BRASIL, Bahia: Vitória da Conquista, estrada da Barra após a entrada do condomínio Alphaville, 19/XI/2019, Moura \& Caires 14 (HUESBVC, HVC); próximo ao condomínio Vogue Alegro, 13/II/2020, Moura \& Caires 26 (HUESBVC, HVC).

Solanum crinitum é uma espécie restrita aos países da América do Sul, sendo registrada na Bolívia, Brasil, Colômbia, Equador, Guianas, Peru e Venezuela (Giacomin; Gomes, 2018). Para o Brasil, a espécie já foi amostrada para quase todos os estados, com exceção da região Sul (SC, RS, PR), Centro-Oeste (MS) e Nordeste (AL, RN) (Giacomin; Gomes, 2018; Flora do Brasil, 2020). Para a Bahia, a espécie é bem amostrada para o sul, centro-oeste, centro-sul e uma porção do oeste do Estado (CRIA, 2020). Habita preferencialmente ambientes secos, áreas de cerrado, restingas e campos rupestres (Agra et al., 2009; Sampaio et al., 2019). Os frutos são considerados tóxicos devido à presença de alcaloides e flavonoides de atividade citotóxica (Araújo et al., 2010). Na área em estudo, a espécie foi em encontrada em um terreno aberto e na borda de mata-de-cipó em regeneração.

13. Solanum palinacanthum Dunal, Prodr. [A.P. de Candolle] 1852;13(1):245. Figura 12a-h.

Arbusto $30 \mathrm{~cm}$ alt., ereta, fortemente aculeada, acúleos $0,3-0,8 \mathrm{~cm}$ de compr., aciculares arroxeados. Caules e ramos cilíndricos, tomentosos, revestidos com tricomas simples, glandulares e estrelados; unidade simpodial difoliada. Folhas simples, discolores, aculeadas, acúleos aciculares ao longo das nervuras, $0,4-1,3 \mathrm{~cm}$ de compr., coriáceas, lâmina 4,2-6,4 × 3,8-5,2 cm, ovada a cordada, ápice agudo, base cordiforme, margem lobada, face adaxial pubescente, com tricomas simples, glandulares, face abaxial com tricomas estrelados sésseis, glandulares; pecíolo 1,3-2,7 cm de compr., cilíndrico. Inflorescência simples, extra-axilar. Botões florais ovoides a oblongos. Flores hermafroditas, pediceladas. Cálice 
Figura 10. Solanum americanum Mill. a: Hábito. b: Detalhe da inflorescência lateral; c-d: Flor; e: Antera com deiscência poricida terminando em fendas; f. Frutos maduros e imaturos.
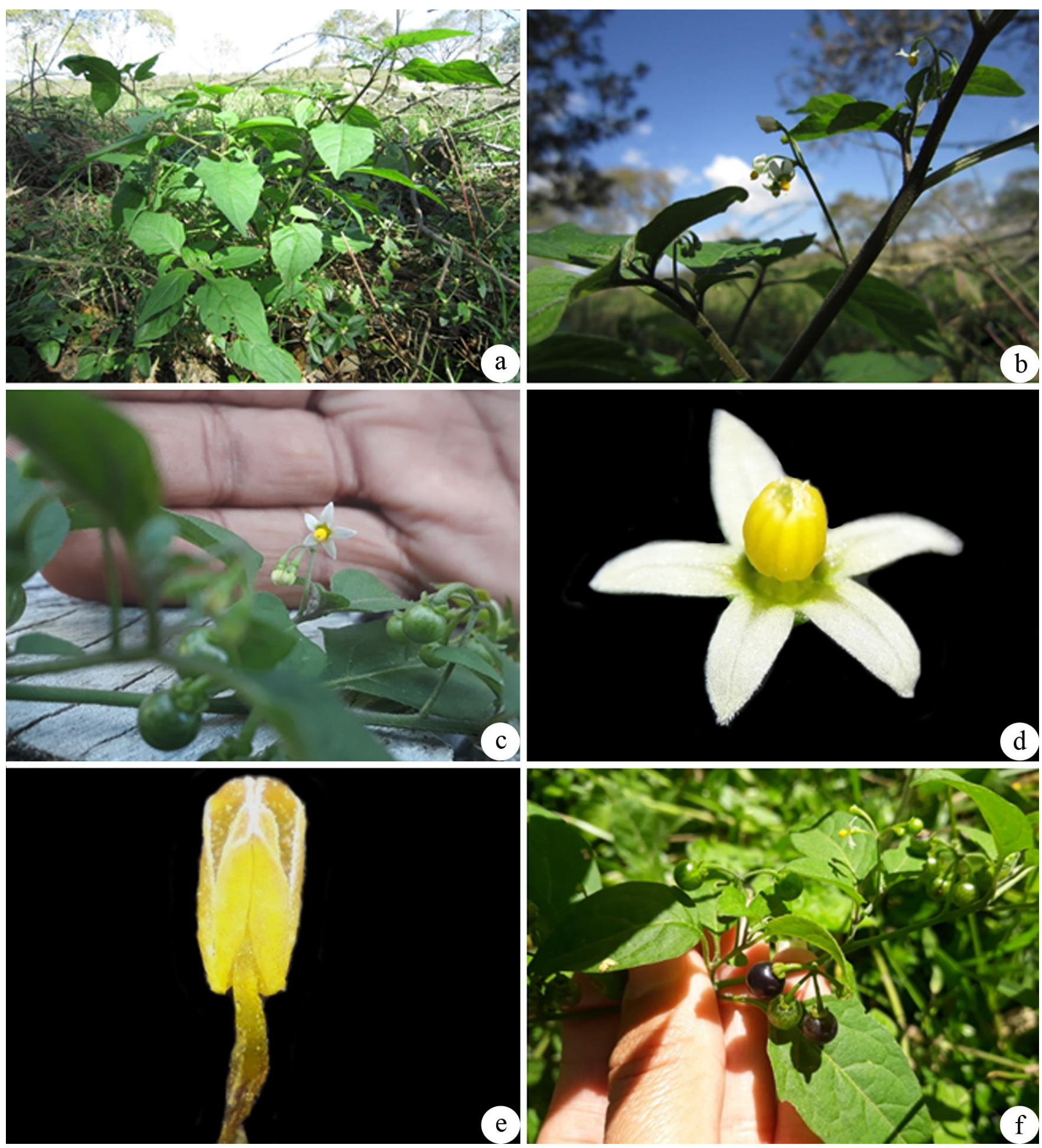
Figura 11. Solanum crinitum Lam. a: Hábito; b-c: Face adaxial e abaxial da folha; d: Detalhe da flor; e: Flor em vista lateral; f: Detalhe do ramo; g: Detalhe do cálice; h: Tricomas.

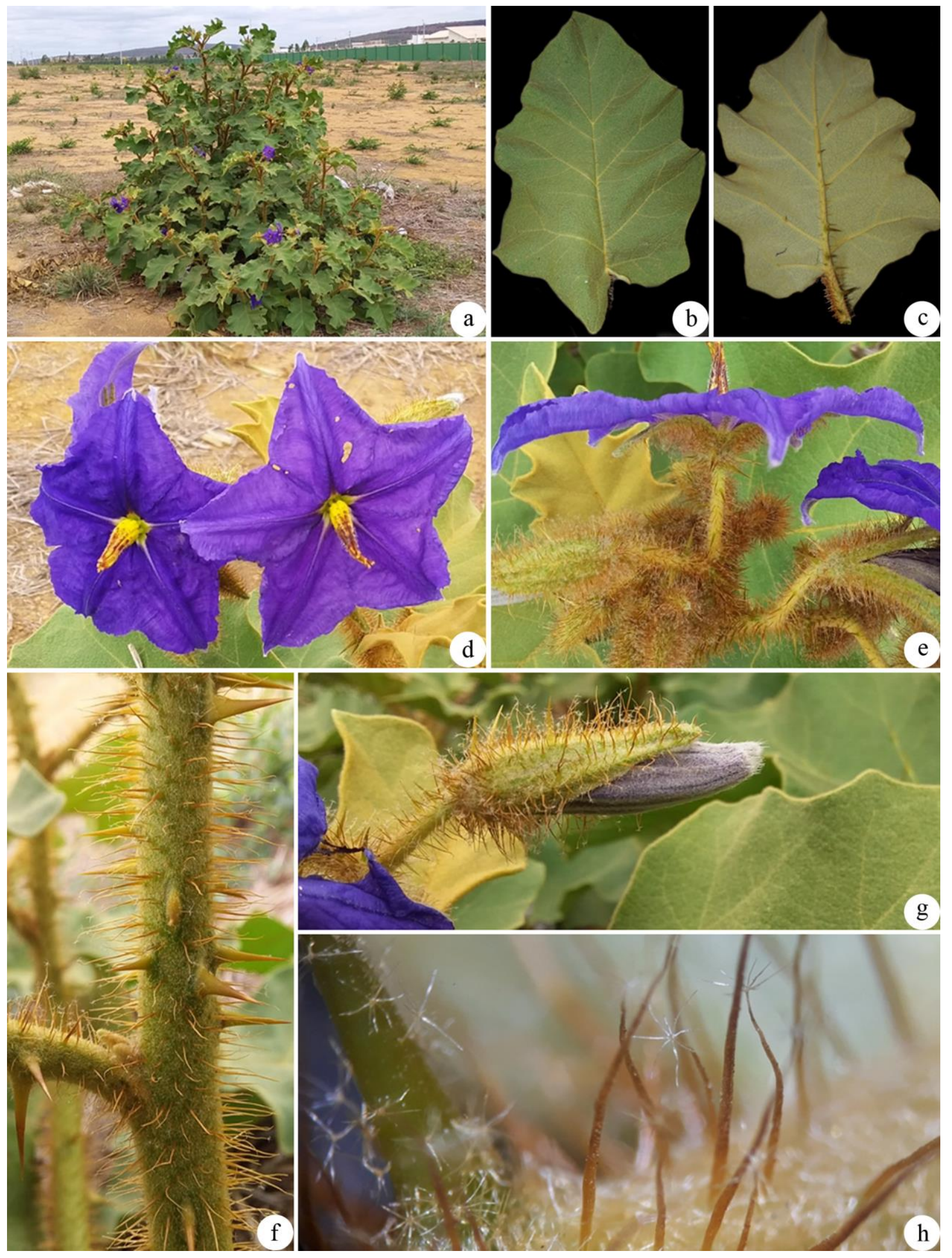


Figura 12. Solanum palinacanthum Dunal. a: Hábito; b-c: Face adaxial e abaxial da folha; d: Detalhe da flor; e-f: Fruto imaturo e maturo; g: Tricoma estrelado-séssil da superfície abaxial da folha; $h$ : Tricomas glandulares simples do caule.
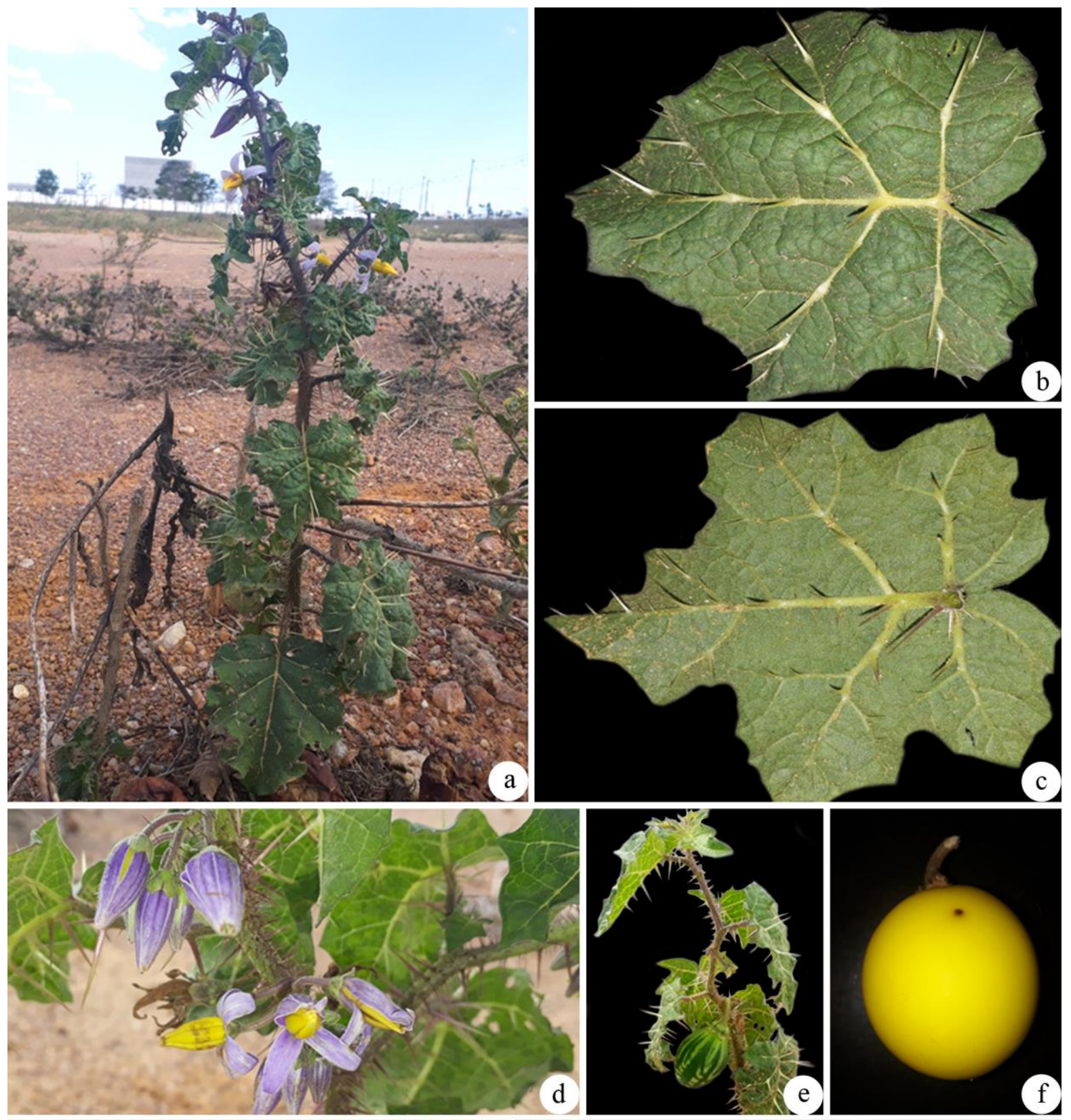

a
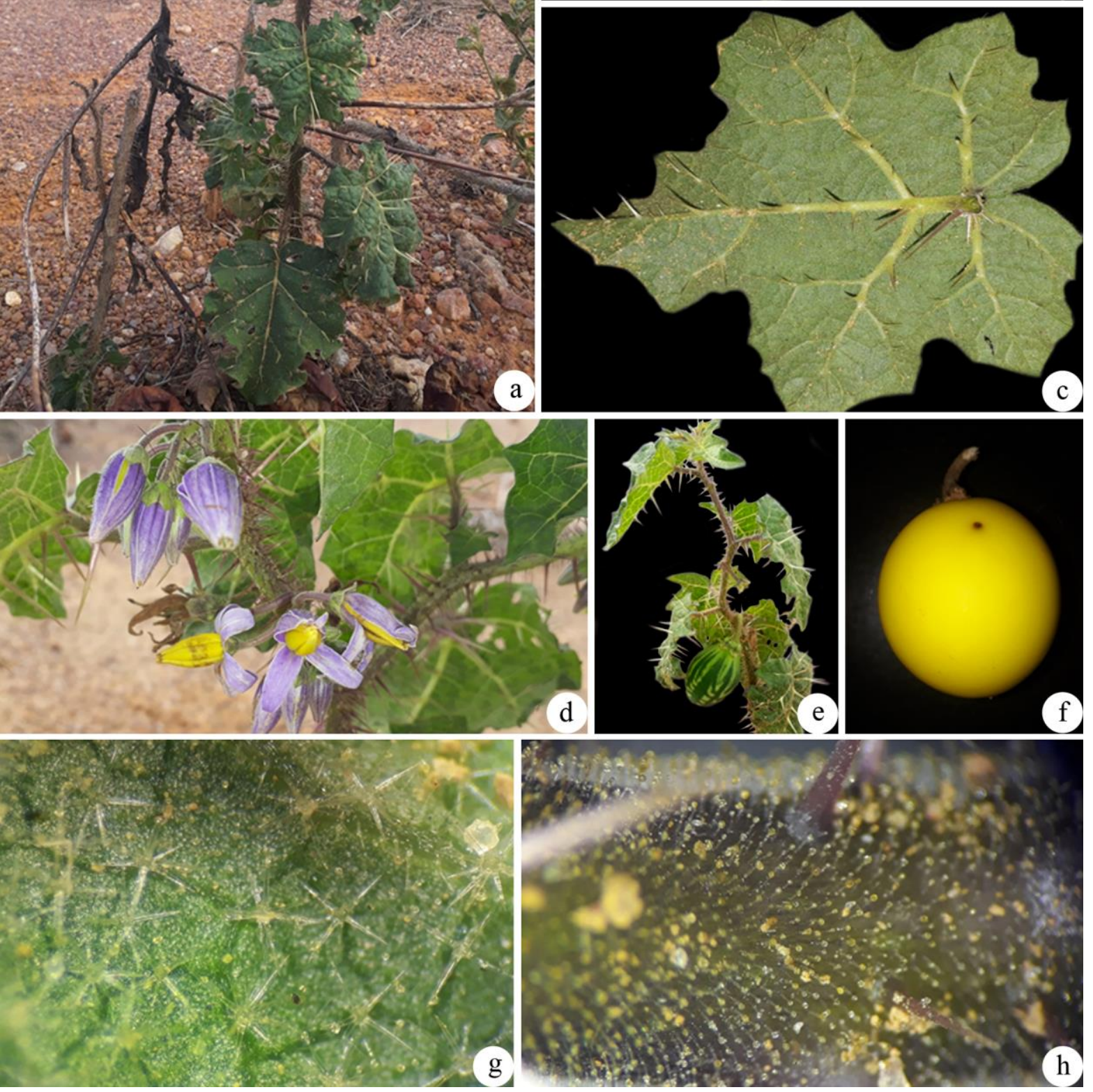
20

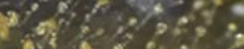


$0,8 \times 0,7 \mathrm{~cm}$, campanulado, lacínias com ápice oval a agudo, tricomas simples e glandulares na face externa. Corola 2,3-2,5 cm de diâm., lilás, estrelada, lacínias lanceoladas, revolutas. Anteras amarelas, oblongas a lanceoladas, deiscência poricida. Estigma capitado, ovário ovoide, pubescente. Baga 2,7 × 2,3 cm, inerme, globosa, epicarpo verde claro, amarelo na maturidade, glabrescente, cálice não envolvendo fruto. Sementes não observadas.

Fenologia: Coletada com flores e frutos maduros em fevereiro e novembro

Material examinado - BRASIL, Bahia: Vitória da Conquista, avenida José Pedral Sampaio, 06/XI/2019, Moura \& Caires 13 (HUESBVC, HVC); próximo à guarita da Universidade Estadual do Sudoeste da Bahia, 04/II/2020, Moura \& Caires 22 (HUESBVC, HVC).

Solanum palinacanthum é uma espécie restrita à América do Sul, ocorrente no Brasil, Bolívia, Paraguai e Argentina. O Brasil possui uma distribuição ampla da espécie, com exceção da região Norte, onde ainda não há registros para os estados do Acre, Amazonas, Roraima e Amapá (Agra et al., 2009; Flora do Brasil, 2020). Para a Bahia, há maior abundância da espécie no centro-oeste, leste, sul do Estado (CRIA, 2020). Habita pastos, terrenos baldios, bordas de estradas, terrenos úmidos, bem como, áreas degradadas (Pereira et al., 2008). Na área em estudo, a espécie foi coletada em margem de estradas e em área aberta.

\section{Solanum paniculatum L., Sp. Pl. 1762;1:267. Figura 13a-g.}

Arbusto $3 \mathrm{~m}$ alt., ereto, aculeado, acúleos 0,2-0,5 cm, cônicos. Caules e ramos cilíndricos, tomentosos, velutinos, com tricomas porrectoestrelados, sésseis ou pedicelados; unidade simpodial plurifoliada. Folhas simples, discolores, cartáceas a subcoriáceas, lâmina 12,3-14,8 $\times 3,8-3,2 \mathrm{~cm}$, inerme ou aculeada, elíptica a lanceolada, ápice acuminado a agudo, base oblíqua, margem lobada, face adaxial pubescente a glabrescente, verde-escuro, face abaxial densamente tomentosa com tricomas estrelados, sésseis ou pediculados, indumento alvo; pecíolo 1,1-3,5 cm de compr., cilíndrico, tomentoso, velutino. Inflorescências terminais, ramificadas, plurifloras, com eixos densamente pilosos. Botões florais ovoides. Flores hermafroditas, pediceladas. Cálice $0,4 \times$ 0,3 mm, campanulado, tomentoso, com tricomas estrelados, lobos acuminados. Corola 2,1-2,4 cm de diâm., alva a lilás, rotáceo-estrelada, partida menos da metade do seu comprimento. Anteras amarelas, lanceoladas, deiscência poricida. Estigma capitado, ovário subgloboso, pubescente. Baga 1,2 × 1,1 cm, globosa, epicarpo glabro, verde com manchas verdes escuras, marrom a nigrescente na maturidade, cálice frutífero não envolvendo o fruto. Sementes não observadas.

Fenologia: Coletada com flores e frutos em agosto e setembro.

Material examinado - BRASIL, Bahia: Vitória da Conquista, margem da estrada da Barra, entre o anel da Avenida Luís Eduardo e a BR, 08/VIII/2019, Moura \& Caires 3 (HUESBVC, HVC); Avenida Luís Eduardo Magalhães, 17/IX/2019, Moura \& Caires 28 (HUESBVC, HVC); próximo ao condomínio Vila Grécia, 17/IX/2019, Moura \& Caires 11 (HUESBVC, HVC).
Solanum paniculatum é uma espécie nativa da América do Sul, encontrada no Brasil, Paraguai e Argentina (Nee, 1999; Mendonça; Lopes, 2019). No Brasil, está amplamente distribuída, ocorrendo em todos os estados, exceto no Amazonas, Acre, Roraima, Amapá e Tocantins (Flora do Brasil, 2020). Para a Bahia, a espécie é bem amostrada, com exceção da região norte, oeste, parte da região sudoeste e extremo sul do Estado (CRIA, 2020).

A espécie possui grande capacidade de adaptação a ambientes hostis e facilmente coloniza áreas abertas, logo, pode ser comumente encontrada em rodovias, bordas de estradas, clareiras e em terrenos baldios, o que lhe confere caráter ruderal (Assunção et al., 2006). Assim como outras espécies da família, S. paniculatum apresenta propriedades medicinais e, portanto, tem despertado grande interesse das indústrias farmacêuticas e em estudos farmacobotânicos (Terço; Lima, 2016). Na área em estudo, a espécie foi encontrada em margens de estradas, sempre em grandes concentrações.

15. Solanum rhytidoandrum Sendtn., Fl. Bras. [Martius] 1846;10:85. Figura 14a-g.

Arbusto 1,53 m alt., ereto, aculeado, acúleos 0,4-0,6 cm de compr., cônicos. Caules e ramos cilíndricos densamente tomentos, com tricomas porrecto-estrelados, pediculados e sésseis; unidade simpodial plurifoliada. Folhas simples, discolores, cartáceas, lâmina 6,5-8,2 × 2,9-6,5 cm, ovada a elíptica, ápice agudo, base oblíqua, margem levemente lobada, face adaxial verde-ferrugíneo, velutina, tomentosa, com tricomas porrecto-estrelados sésseis e pediculados, face abaxial verde cinéreo, velutina, tricomas porrecto estrelados, acúleos 0,2-0,4 $\mathrm{mm}$ de compr., esparsos na nervura principal; indumento ferrugíneo; pecíolo $0,8-1,9 \mathrm{~cm}$ de compr., tomentoso, aculeado. Inflorescências ramificadas, terminais, plurifloras, tomentosas. Botões florais ovoides. Flores hermafroditas, pediceladas. Cálice $0,5 \times 0,4 \mathrm{~mm}$, campanulado, tomentoso, tricomas porrecto-estrelados, lobos lanceolados, ápice agudo. Corola 2,0-2,7 $\mathrm{cm}$ de diâm., alva a creme, estrelada, lobos lanceolados. Anteras amarelas, lanceoladas, deiscência poricida. Estigma capitado, ovário subgloboso, revestido por tricomas glandulares e simples. Baga $1,4 \times$ $1,2 \mathrm{~cm}$, globosa, inerme, epicarpo piloso a pubescente, com tricomas glandulares e estrelados, cálice frutífero não envolvendo o fruto. Sementes não observadas.

Fenologia: Coletada com flores e frutos imaturos em fevereiro, setembro e novembro.

Material examinado - BRASIL, Bahia: Vitória da Conquista, próximo ao condomínio Morada Jardim Guanabara, 17/IX/2019, Moura \& Caires 12 (HUESBVC, HVC); fundo do condomínio Alphaville, próx. à guarita da Universidade Estadual do Sudoeste da Bahia, 19/XI/2019, Moura \& Caires 17 (HUESBVC, HVC); lateral do muro do Alphaville 2, 13/II/2020, Moura \& Caires 30 (HUESBVC, HVC); próximo ao Residencial Palmira Bittencourt, 13/II/2020, Moura \& Caires 27 (HUESBVC, HVC). 
Figura 13. Solanum paniculatum L. a: Hábito; b: Face adaxial da folha; c-d: Detalhes da flor; e: Anteras com deiscência poricida; f: Tricoma estrelado da superfície abaxial da folha; g: Frutos imaturos.
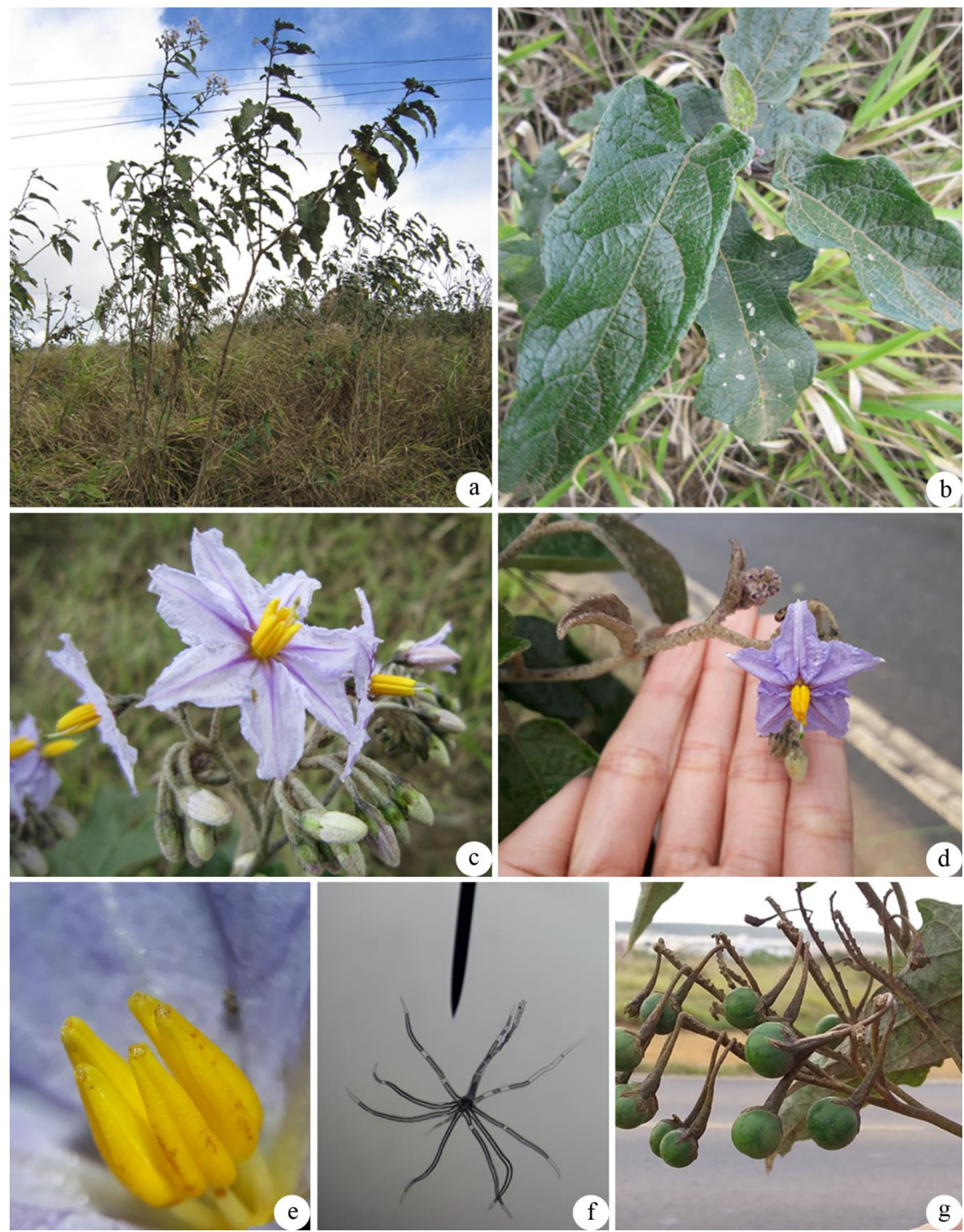
Figura 14. Solanum rbytidoandrum Sendtn. a: Hábito; b-c: Face adaxial e abaxial da folha; d: Inflorescência e ramo piloso; e: Detalhe da flor; f: Tricoma estrelado-séssil da superfície adaxial da folha; g: Fruto imaturo.

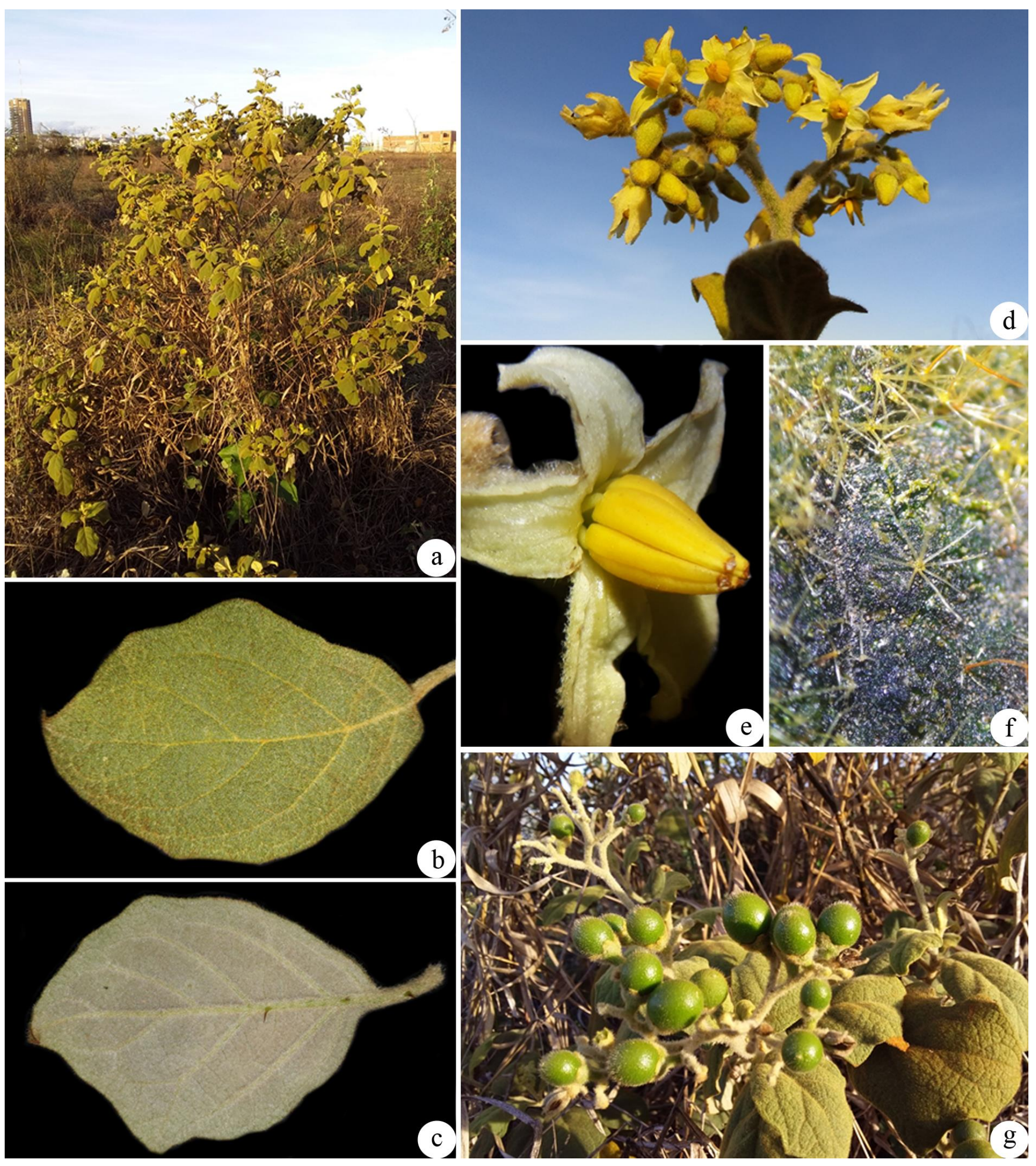


Solanum rbytidoandrum é uma espécie nativa da América do Sul, bem representada na Bolívia, Paraguai e Brasil, em áreas do semiárido (Agra et al., 2009). No Brasil, a espécie é distribuída nas regiões Norte (AM, PA, RO, TO), Nordeste (BA, CE, MA, PB, PE, PI, RN) e CentroOeste (DF, GO, MS, MT), nos domínios fitogeográficos da Amazônia, Caatinga e Cerrado (Flora do Brasil, 2020). Na Bahia, a espécie ainda é pouco amostrada (CRIA, 2020) e é encontrada frequentemente em ambientes secos, de restingas, brejos ou em matas secundárias (Agra et al., 2009). Na área em estudo, a espécie foi encontrada em áreas de regeneração e terrenos baldios.

16. Solanum sisymbriifolium Lam., Tabl. Encycl. 1794;2:25. Figura $15 \mathrm{a}-\mathrm{g}$.

Subarbusto $65 \mathrm{~cm}$ alt., ereto, fortemente aculeado, acúleos $0,5-0,8$ $\mathrm{mm}$ de compr., aciculares. Caules e ramos cilíndricos, pubescentes, revestidos por tricomas simples e glandulares, raramente estrelados; unidade simpodial plurifoliada. Folhas discolores, pinatissectas, membranáceas, lâmina 5,2-16,4 × 3,5-10,2 cm, ovada a oblonga, ápice agudo, base assimétrica, face adaxial revestida por tricomas simples, glandulares, raramente estrelados, face abaxial pilosa, revestida por tricomas estrelados, acúleos aciculares presentes; pecíolo 1,4-3,9 cm de compr., cilíndrico. Inflorescências simples, extra-axilares, escorpioides, pubescentes. Botão floral elipsoide. Flores hermafroditas, pediceladas. Cálice 1,3 $\times 1,2 \mathrm{~cm}$, campanulado, fortemente armado, piloso, com tricomas glandulares e simples, lacínias triangulares a lanceoladas. Corola 2,1-2,2 cm de diâm., branca, rotáceo-estrelada, partida menos da metade do seu comprimento, lobos triangulares. Anteras amarelas, lanceoladas, deiscência poricida. Estigma capitado, ovário globoso, glabro. Baga $1,8 \times 1,7 \mathrm{~cm}$, epicarpo verde quando jovem, vermelho a negro na maturidade, glabro, cálice frutífero envolvendo o fruto, fortemente armado. Sementes não observadas.

Fenologia: Coletada com flores e frutos maduros em janeiro.

Material examinado - BRASIL, Bahia: Vitória da Conquista, Avenida Eduardo Campos, 23/I/2020, Moura \& Caires 19 (HUESBVC, HVC).

Solanum sisymbriifolium é uma espécie nativa das regiões secas da América do Sul e atualmente encontra-se bastante distribuída nas regiões tropicais e subtropicais (Sampaio et al., 2019). Apesar de ser nativa da América do Sul, a espécie já foi introduzida na América do Norte, em alguns países dos continentes Europeu, Africano, Asiático e também para a região da Australásia (Srivastava et al., 2015). No Brasil, distribui-se pela região Norte (AC, RO), Nordeste (BA), Centro-Oeste (DF, GO, MS, MT), Sudeste (ES, MG, RJ, SP) e Sul (PR, RS, SC), abrangendo todos os domínios fitogeográficos (Flora do Brasil, 2020). Na Bahia, a espécie ainda é pouco amostrada (CRIA, 2020). Solanum sisymbriifolium possui propriedades medicinais, sendo utilizadas as raízes como diurético, analgésico e contraceptivo (Srivastava et al., 2015). Para a área em estudo, a espécie foi encontrada em margem de estrada em área antropizada.
17. Solanum stipulaceum Willd. ex Roem. \& Schult., Syst. Veg. 1819;4:662. Figura 16a-h.

Arbusto $1,55 \mathrm{~m}$ alt., ereto, inerme. Caules e ramos cilíndricos, estriados, densamente pilosos, cobertos com tricomas estrelados sésseis; unidade simpodial plurifoliada. Folhas simples, discolores, membranáceas a subcoriáceas, lâmina 4,5-10,5 $\times 2,4-3,6 \mathrm{~cm}$, lanceolada, ápice acuminado a agudo, base atenuada, margem inteira, face adaxial verde escuro, moderadamente pilosas, com tricomas estrelados, face abaxial velutina, com tricomas estrelados; pecíolo 0,9-2,6 cm de compr., cilíndrico, associado a uma pseudoestípula auriculada. Inflorescências ramificadas, escorpioides, plurifloras, com muitas flores concentradas no ápice do ramo. Flores hermafroditas, pediceladas. Cálice $0,6 \times 0,5 \mathrm{~mm}$, campanulado, densamente coberto por tricomas na face abaxial, sépalas parcialmente soldadas. Corola 0,9-1,2 cm de diâm., lilás, estrelada, lobos triangulares, com muitos tricomas na face abaxial. Anteras amarelas, oblongas, deiscência poricida. Estigma globoso, ovário subgloboso, glabro. Baga 1,3 × 1,2 cm, globosa, inerme, pubescente, epicarpo verde cinéreo quando imaturo, cálice frutífero não envolvendo o fruto, apresentando tricomas esparsos. Sementes numerosas, marrons, sub-reniformes.

Fenologia: Coletada com flores e frutos imaturos em agosto.

Material examinado - BRASIL, Bahia: Vitória da Conquista, em frente ao Módulo Amélia Barreto da Universidade Estadual do Sudoeste da Bahia, 01/VIII/2019, Moura \& Caires 1 (HUESBVC, HVC).

Solanum stipulaceum é uma espécie nativa e endêmica do Brasil, ocorre no Nordeste (AL, BA, CE, PB, PE, PI, SE), Centro Oeste (GO) e Sudeste (MG) e é frequentemente distribuída em áreas de matas secas, bordas de estradas, áreas antropizadas, terrenos baldios bem como, regiões montanhosas, áreas de Savana, Savana Estépica e Floresta Ombrófila (Agra et al., 2009; Sampaio et al., 2019). Na Bahia, a espécie é bem amostrada para todo o Estado (CRIA, 2020). Na área em estudo, a espécie foi coletada em área urbana, sendo comum em todos os fragmentos antropizados do município.

18. Solanum thomasiifolium Sendtn., Fl. Bras. [Martius] 1846;10:74. Figura $17 \mathrm{a}-\mathrm{g}$.

Arbusto 1,60 m alt., ereto, aculeado, acúleos 0,6-1,0 cm de compr., cônicos, ferrugíneos. Caules e ramos cilíndricos, pubescentes, velutinos, indumento ferrugíneo, revestido por tricomas glandulares estrelados, sésseis; unidade simpodial difoliada. Folhas simples, solitárias, subcoriáceas, lâmina 2,5-4,5 × 2,3-3,4 cm, ovada a elíptica, ápice agudo, base cordada, margem inteira a lobada, ambas as faces tomentosas, velutinas, revestidas por tricomas glandulares estrelados sésseis, acúleos esparsos ao longo da nervura principal; pecíolo 0,6$1,5 \mathrm{~cm}$ de compr., cilíndrico, tomentoso. Inflorescências simples, extra-axilares, plurifloras, tomentosas. Flores hermafroditas, pediceladas. Cálice $1,1 \times 1,0 \mathrm{~cm}$, campanulado, sépalas partidas mais da metade do seu comprimento, lobos triangulares, ápice acuminado, 
Figura 15. Solanum sisymbriifolium Lam. a: Hábito; b: Detalhe da lâmina foliar; c: Detalhe da flor; d: Inflorescência; e: Cálice frutífero armado; f: Fruto maduro; g: Tricomas da lâmina foliar.
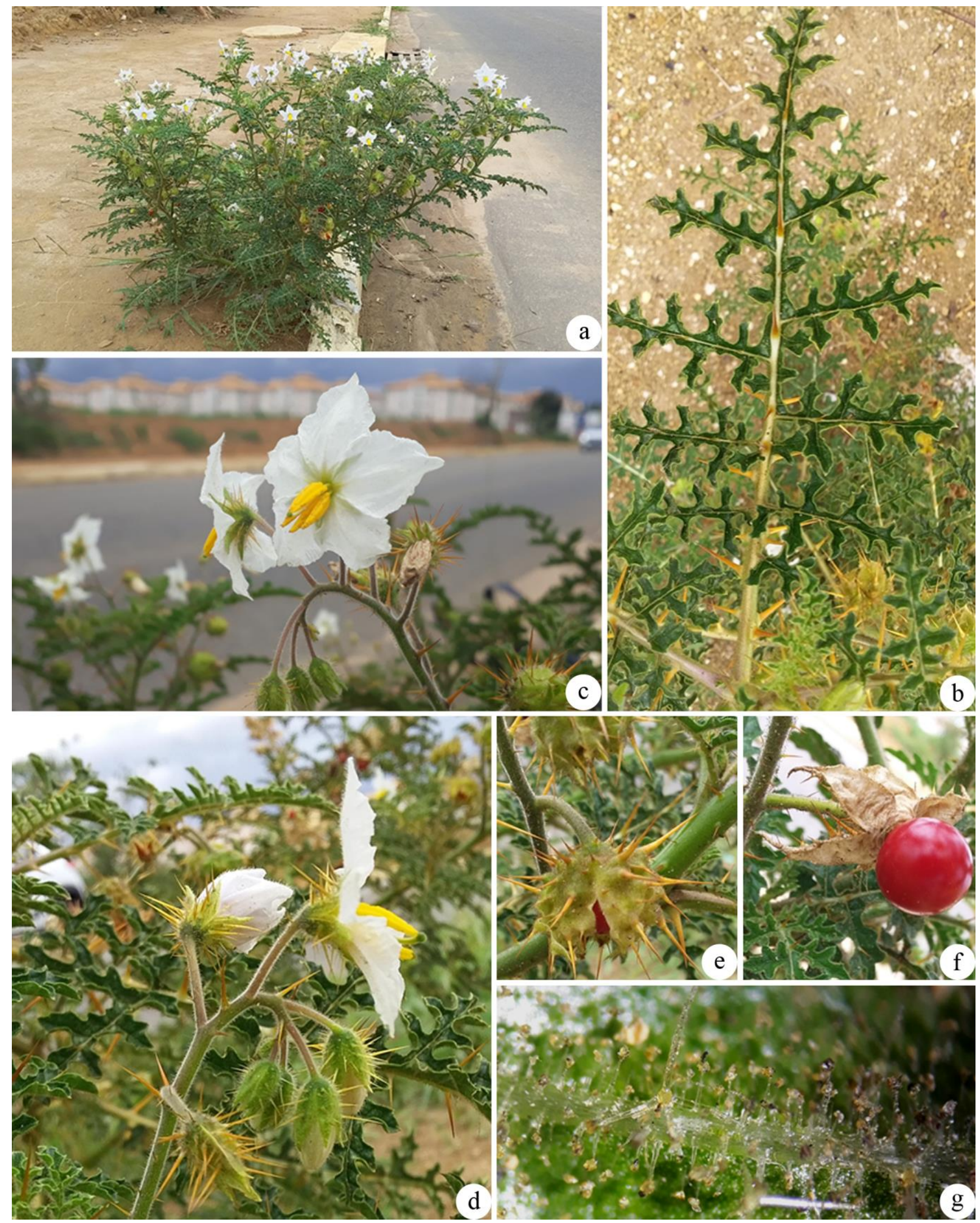
Figura 16. Solanum stipulaceum Willd. ex Roem. \& Schult. a: Hábito; b: Face adaxial e abaxial da folha; c: Detalhe da flor; d: Detalhe do cálice e pétalas; e: Indumento da corola; f: Anteras com deiscência poricida; g: Pseudoestípula auriculada; h: Fruto imaturo.
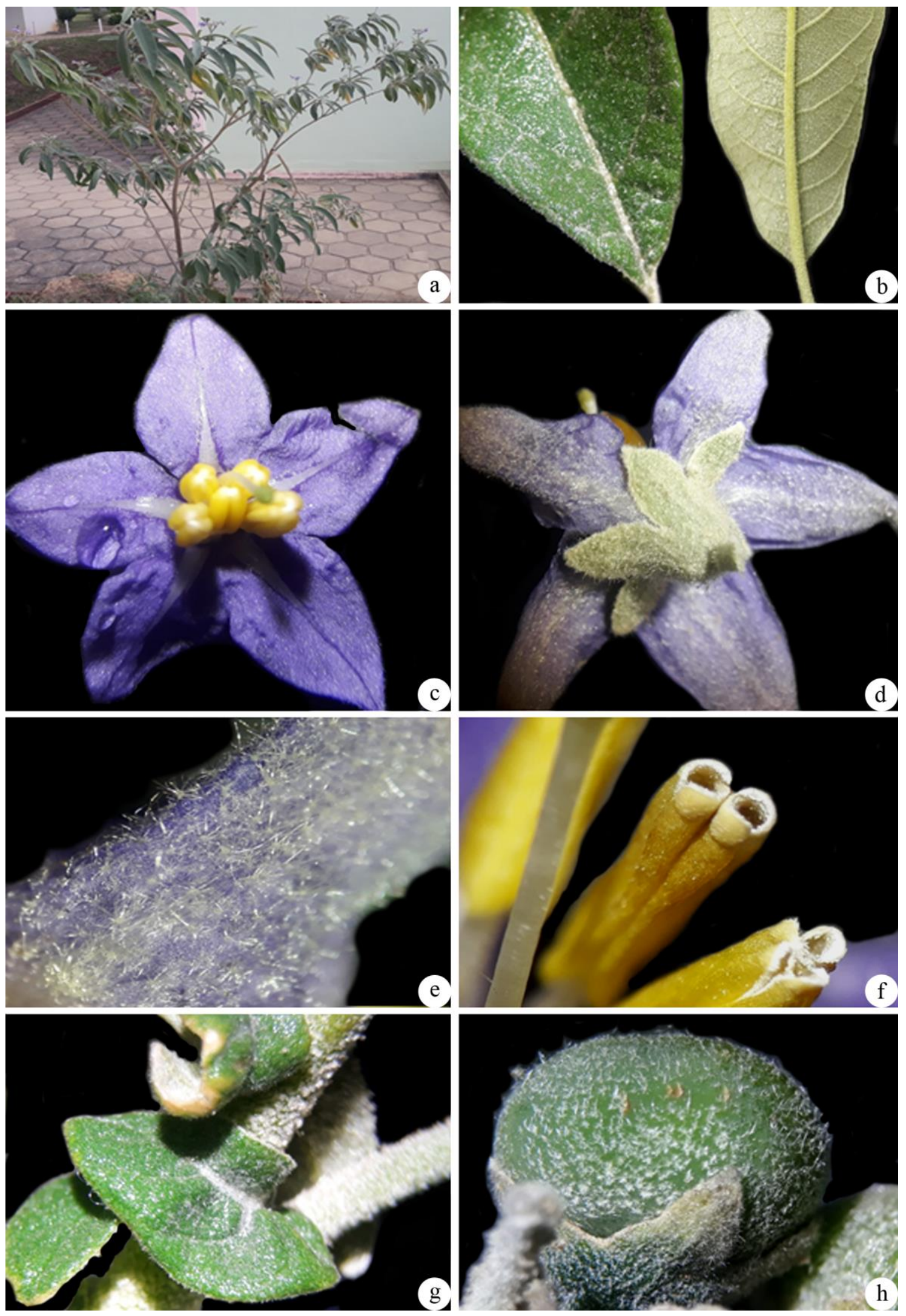
Figura 17. Solanum thomasiifolium Sendtn. a: Hábito; b-c: Detalhes da flor; d: Inflorescência e botões florais; e: Tricoma estrelado glandular da superfície abaxial da folha; f: Anteras com deiscência poricida; g: Frutos imaturos.
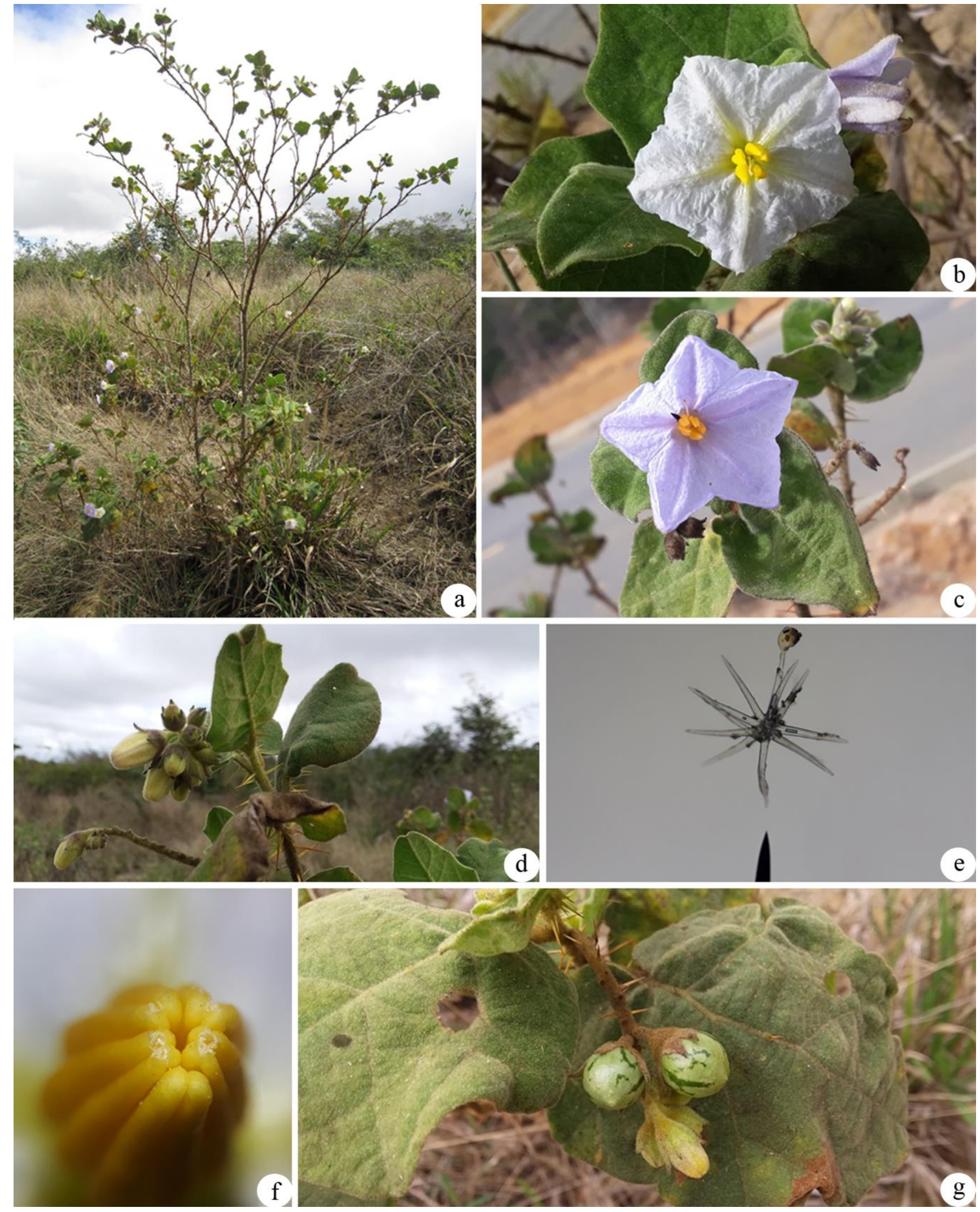
revestido por tricomas glandulares. Corola $1,7 \times 2,0 \mathrm{~cm}$ de diâm., branca ou lilás, rotada, pétalas soldadas na maior parte do seu comprimento, lobos agudos; anteras amarelas, lanceoladas, deiscência poricida. Estigma capitado, ovário subgloboso, pubescente. Baga 1,2 $\times 1,1 \mathrm{~cm}$, globosa, inerme, epicarpo verde claro com manchas quando imaturo, glabrescente, revestido por tricomas glandulares estrelados, cálice frutífero não envolvendo o fruto. Sementes não observadas.

Fenologia: Coletada com flores e frutos imaturos em agosto.

Material examinado - BRASIL, Bahia: Vitória da Conquista, margem da estrada lateral da Universidade Estadual do Sudoeste da Bahia, próximo à guarita da Matinha, 08/VIII/2019, Moura \& Caires 4 (HUESBVC, HVC).

Solanum thomasiifolium é uma espécie endêmica do Brasil e distribuise pela região Nordeste (AL, BA, SE), Centro-Oeste (GO) e Sudeste (ES, MG), em domínios fitogeográficos da Caatinga, Cerrado e Mata Atlântica. Nessas regiões, espalha-se por áreas secas da Caatinga, Cerrado e Campos Rupestres (Agra, 2007; Flora do Brasil, 2020). Na Bahia, há uma maior distribuição da espécie no centro-norte, centroleste, parte do Sudoeste e no litoral baiano (CRIA, 2020). Para a área em estudo, a espécie foi encontrada em margem de estrada, em ambiente seco com mata em regeneração.

19. Solanum viarum Dunal, Prodr. [A.P. de Candolle] 1852;13:240. Figura 18a-f.

Arbusto $30 \mathrm{~cm}$ alt., ereto, aculeado, acúleos 0,3-1,2 cm de compr., aciculares esverdeados. Caules e ramos cilíndricos, pilosos, com tricomas simples e glandulares; unidade simpodial difoliada. Folhas simples, solitárias ou geminadas, pilosas, cartáceas, lâmina 4,5-7,4 $\times$ 3,9-6,6 cm, ovada, ápice agudo, base cordada, margem lobada, lobos agudos, acúleos, 0,5-1,5 cm de compr., face adaxial pubescente, revestida por tricomas simples e glandulares, face abaxial tomentosa, com tricomas simples e estrelados; pecíolo 3,2-4,5 cm de compr., cilíndrico. Inflorescência simples, extra-axilar ou lateral, pubescente. Botões florais elipsoides. Flores hermafroditas, pediceladas. Cálice 0,8-0,7 mm de compr., campanulado, sépalas soldadas até metade do seu comprimento, lobos lanceolados, tricomas simples e glandulares. Corola 2,0-2,5 cm de diâm., branca, estrelada, lobos lanceolados, revolutos; anteras brancas, lanceoladas, deiscência poricida. Estigma capitado, ovário subgloboso. Baga 3,5 × 3,4 cm, globosa, epicarpo glabrescente, verde quando jovem e amarelo quando maturo, cálice frutífero não acrescente. Sementes não observadas.

Fenologia: Coletada com flores e frutos maduros em agosto.

Material examinado -BRASIL, Bahia: Vitória da Conquista, curral próximo ao CETEP, localizado na Universidade Estadual do Sudoeste da Bahia, 20/VIII/2019, Moura \& Caires 9 (HUESBVC, HVC).

Solanum viarum é uma espécie nativa do Brasil e Argentina, frequentemente encontrada em toda a América do Sul, México, Honduras, Caribe, África, Índia, Nepal (Nee, 1991). No Brasil, distribui-se pela região Norte (AC, RO), Nordeste (AL, BA, PB), Centro-Oeste (DF, GO, MS, MT), Sudeste (ES, MG, RJ, SP) e Sul
(PR, RS, SC), nos domínios Amazônia, Mata Atlântica, Cerrado e Pantanal (Sampaio, 2013; Flora do Brasil, 2020). Na Bahia, a espécie está concentrada nas regiões sul e leste (CRIA, 2020). Solanum viarum é considerada uma erva daninha e coloniza áreas de lavouras anuais, pastagens, terrenos baldios e bordas de estradas. Desenvolve-se preferencialmente em ambientes úmidos e arenosos e seus frutos, quando maduros, são tóxicos (Mendonça; Lopes, 2019). Na área em estudo, a espécie foi encontrada em uma pastagem, em local úmido.

\section{Conclusão}

A família Solanaceae apresentou-se com grande diversidade no presente estudo (nove gêneros e 19 espécies), evidenciando não só a riqueza da área estudada, mas também a qualidade do ambiente, onde seu comportamento como pioneira, observado em espécies subespontâneas e ruderais, confere a essas plantas um papel fundamental na reestruturação das comunidades vegetais. Observouse que os gêneros e as espécies foram encontrados em diferentes fisionomias vegetais, sendo o gênero Solanum o mais abundante, colonizando todos os ambientes analisados. Algumas espécies estiveram presentes só em ambientes mais áridos, como $S$. sisymbriifolium, enquanto outras desenvolveram-se em locais mais úmidos, como S. americanum. Nossos resultados demonstram a necessidade de preservação das variadas comunidades vegetais, com a elaboração de ações conservacionistas, visto que estas abrigam diversas formas de vida que auxiliam no processo de estruturação ecológica dos fragmentos florestais.

\section{Agradecimentos}

À Dra. Greta Aline Dettke, pelo tratamento das pranchas. À Dra. Maria Rosa Vargas Zanatta, pela confecção dos mapas de distribuição geográfica. À Universidade Estadual do Sudoeste da Bahia, pelo apoio logístico; Ao Laboratório de Botânica, pelo espaço e pelos equipamentos necessários para o desenvolvimento da pesquisa; e à Fundação de Amparo à Pesquisa do Estado da Bahia (FAPESB), pela concessão da bolsa de Iniciação Científica à primeira autora.

\section{Financiamento}

A Fundação de Amparo à Pesquisa do Estado da Bahia (FAPESB) concedeu bolsa de Iniciação Científica à primeira autora.

\section{Contribuições de Autoria}

Conceitualização: CSC. Curadoria de dados: JNM. Análise formal: JNM. Aquisição de financiamento: CSC. Investigação: JNM, CSC. Metodologia: JNM, CSC. Administração do projeto: CSC. Recursos: CSC. Supervisão: CSC. Redação - rascunho original: JNM. Redação - revisão e edição: JNM, CSC. 
Figura 18. Solanum viarum Dunal. a: Hábito; b: Face adaxial da folha; c-d: Detalhe da flor e das anteras; e: Indumento das folhas; f: Frutos maduros.
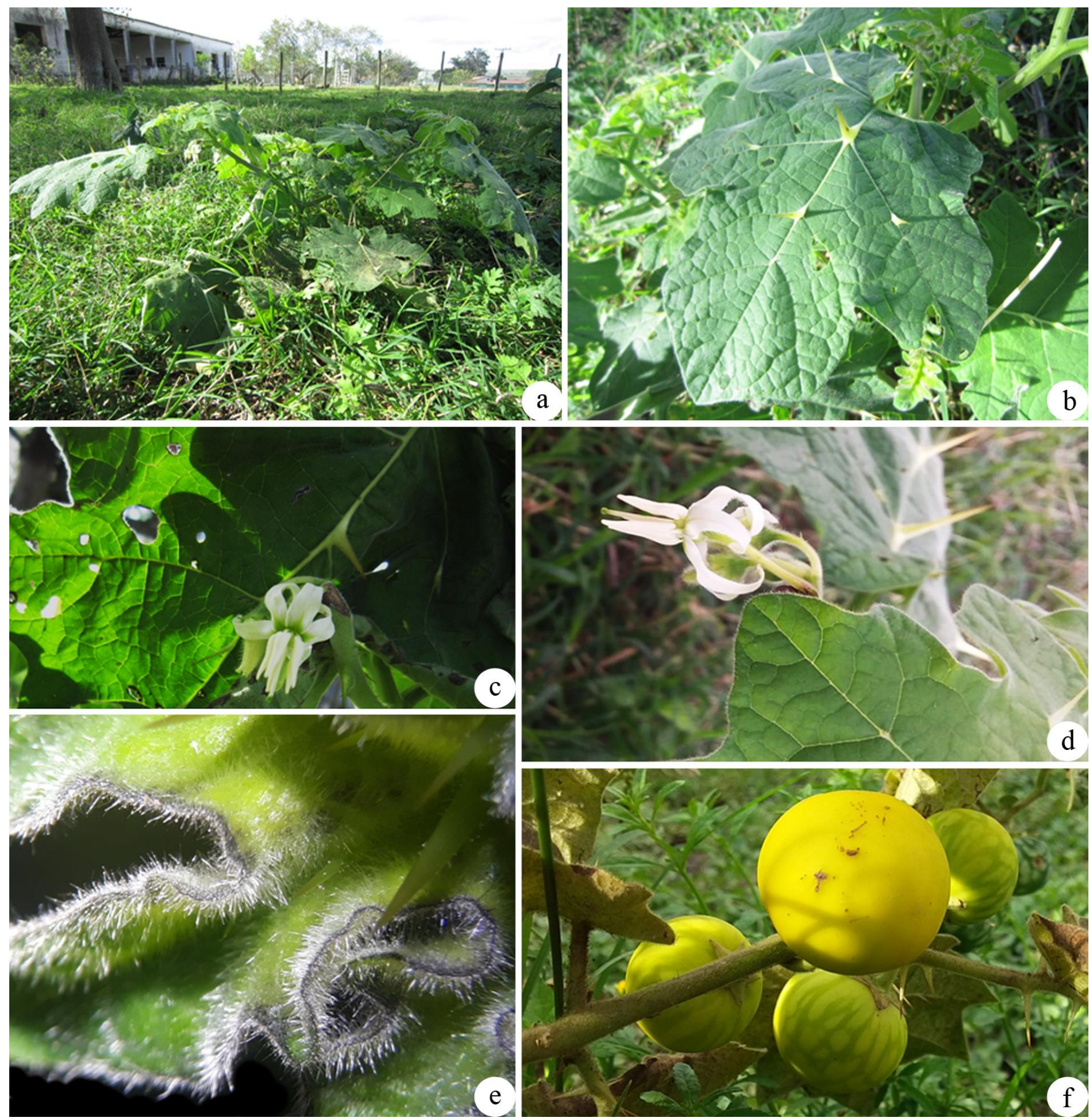

Disponibilidade dos Dados

Os dados integrais analisados durante o estudo atual estão apresentados no corpo do manuscrito e os espécimes serão depositados nos herbários HUESBVC e HVC.

Conformidade Ética

Não se aplica.

\section{Referências}

Agra MF. A new species of Solanum section Micracantha

(Solanaceae) from Northeastern Brazil. Novon 1992;2(3):179181. doi: $10.2307 / 3391542$

Agra MF. A new species of Solanum subgenus Leptostemonum (Solanaceae) from Chapada Diamantina, Bahia, Brazil. Novon 1999a;9(3):292-295. doi:10.2307/3391723 
Agra MF. Diversity and distribution of Solanum subgenus Leptostemonum in Northeast of Brazil. In: Nee M, Symon D, Lester RN, Jessop JP, editors. Solanaceae IV. Advances in Biology and Utilization. Kew: Royal Botanical Gardens; 1999b. p. 197-203.

Agra MF. Solanaceae. In: Barbosa MRV, Sothers C, Mayo S, Gamarra C, organizadores. Checklist das Angiospermas do Nordeste. Brasília: Ministério da Ciência e Tecnologia; 2006. p. 146-148.Agra MF. Diversity and distribution of Solanum subg. Leptostemonum in Brazil. Acta Horticulturae 2007;745(1):31-43.

doi:10.17660/ActaHortic.2007.745.1

Agra MF. Solanaceae. In: Alves M, Araújo MF, Maciel JR, Martins S. Flora de Mirandiba. Recife: Associação Plantas do Nordeste; 2009. p. 339-344.

Agra MF, Silva KN, Berger LR. Flora da Paraíba, Brasil: Solanum L. (Solanaceae). Acta Botanica Brasilica 2009;23(3):826-842. doi:10.1590/S0102-33062009000300024

Al-Snafi AE. The pharmacological importance of Capsicum species (Capsicum annum and Capsicum frutescens Grown) in Iraq. Journal of Pharmaceutical Biology 2015;5(3): 124-142.

Al-Snafi AE. Medical importance of Datura fastuosa (syn: Datura mete) and Datura stramonium - A review. Journal of Pharmacy. 2017;7(2): 43-58. doi:10.9790/3013-0702014358

Althaus-Ottmann MM, Leal L, Zuffellato-Ribas KC. Propagação vegetativa de manacá (Brunfelsia uniflora (Pohl.) D.Don). Revista Brasileira de Horticultura Ornamental 2006;12(1): 31-36. doi:10.14295/rbho.v12i1.4

Alves M, Oliveira RB, Teixeira SR, Guedes MLS, Roque N. Levantamento florístico de um remanescente de Mata Atlântica no litoral norte do Estado da Bahia, Brasil. Hoehnea 2015;42(3):581595. doi:10.1590/2236-8906-06/2015

Amorim AM, Jardim JG, Lopes MMM, Fiaschi P, Borges RAX, Perdiz RO, Thomas WW. Angiospermas em remanescentes de Floresta Montana no sul da Bahia, Brasil. Biota Neotropica 2009;9(3):313-438. doi:10.1590/S1676-060320090003300028

APG IV. An update of the Angiosperm Phylogeny Group classification for the orders and families of flowering plants: APG IV. Botanical Journal of the Linnean Society 2016;181(1):1-20. doi: $10.1111 /$ boj. 12385

Araújo ND, Coelho VPM, Agra MF. Estudo farmacobotânico comparativo de folhas de Solanum crinitum Lam., Solanum gomphodes Dunal e Solanum lycocarpum A.St.-Hil., Solanaceae. Revista Brasileira de Farmacognosia 2010;20(5):666-674. doi:10.1590/S0102$\underline{695 X 2010005000016}$

Assunção IP, Lima GSA, Amorim EPR, Muniz MFS, Endres L. Ocorrência de Curvularia lunata em Jurubeba no estado de Alagoas. Summa Phytopathologica 2006;32(4):386-387. doi:10.1590/S0100$\underline{54052006000400014}$

Barbosa MRV et al. Checklist of the vascular plants of the Guaribas Biological Reserve, Paraíba, Brazil. Revista Nordestina de Biologia 2011;20(2):79-106.

Barboza GE, Hunziker AT, Bernardello G, Cocucci AA, Moscone AE, Carrizo-García C, Fuentes V, Dillon MO, Bittrich V, Costa MT, Subils R, Romanutti A, Arroyo S, Anton A. Solanaceae. In: Kadereit JW, Bittrich V, editors. The families and genera of vascular plants: flowering plants. Eudicots. v. 14. Switzerland: Springer; 2016. p. 295-357. doi:10.1007/978-3-319-28534-4 29

Carvalho LAF, Bovini MG. Solanaceae na reserva Rio das Pedras, Mangaratiba, Rio de Janeiro - Brasil. Rodriguésia 2006;57(1):75-98. doi: $\underline{10.1590 / 2175-7860200657106}$
Carvalho LAF, Costa LHP, Duarte AC. Diversidade taxonômica e distribuição geográfica das solanáceas que ocorrem no Sudeste brasileiro (Acnistus, Athenaea, Aureliana, Brunfelsia e Cyphomandra). Rodriguésia 2001;52(80):31-45. doi:10.1590/2175-78602001528003

Carvalho SIC, Bianchetti LB, Ribeiro CSC, Lopes CA. Pimentas do gênero Capsicum no Brasil. Documentos 94. Brasília: Embrapa hortaliças; 2006.

Centro de Referência e Informação Ambiental - CRIA [Internet]. [acesso em 25 out 2020 - Código da busca: 109785_20201025101453]. Disponível em http://www.splink.org.br/

Costa-Silva R, Agra MF. Updates on Lycianthes (Solanaceae): a new species from Brazil, notes on taxonomy, and a key to identification of Brazilian species. Nordic Journal of Botany. 2018;36(10):19-49. doi: $10.1111 /$ njb.01949

Dunal MF. Solanaceae. In: de Candolle ALPP, editor. Prodromus systematis naturalis regni vegetabilis, v. 13, pt.1. Parisii: Victoris Masson; 1852.

Fabricante JR, Castro RA, Araújo KCT, Siqueira-Filho JA. Atributos ecológicos da bioinvasora Nicotiana glauca Graham (Solanaceae) e avaliação da susceptibilidade de sua ocorrência no Brasil. Ciência Florestal 2015;25(4): 959-967. doi:10.5902/1980509820650

Feliciano EA, Salimena FRG. Solanaceae na Serra Negra, Rio Preto, Minas Gerais. Rodriguésia 2011;62(1):55-76. doi:10.1590/2175$\underline{7860201162105}$

Filgueiras TS, Nogueira PE, Brochado AL, Guala GF.

Caminhamento: um método expedito para levantamentos florísticos qualitativos. Cadernos de Geociências 1994;12:39-43.

Flora do Brasil 2020 em construção [internet]. Rio de Janeiro: Jardim Botânico do Rio de Janeiro [acesso em 25 out 2020] Disponível em: http://floradobrasil.jbri.gov.br/reflora/floradobrasil/FB225

Giacomin LL. Estudos taxonômicos e filogenéticos em Solanum sect. Gonatotrichum Bitter (Solanoideae, Solanaceae) no Brasil

[dissertação]. Belo Horizonte, MG: Universidade Federal de Minas Gerais; 2010.

Giacomin LL, Gomes ESC. Flora das cangas da Serra dos Carajás, Pará, Brasil: Solanaceae. Rodriguésia 2018;69(3):1373-1396. doi:10.1590/2175-7860201869332

Giacomin LL, Stehmann JR. A new heterandrous species of Solanum section Gonatotrichum Bitter (Solanaceae) from Bahia, Brazil. PhytoKeys 2011;7(1):1-9. doi:10.3897/phytokeys.7.1855

Giorgetti M, Negri G. Plants from Solanaceae family with possible anxiolytic effect reported on 19th century's Brazilian medical journal. Revista Brasileira de Farmacognosia 2011;21(4):772-780. doi:10.1590/S0102-695X2011005000106

Guaraná ELS, Riet-Correa F, Mendonça CL, Medeiros RMT, Costa NA, Afonso JAB. Intoxicação por Solanum paniculatum (Solanaceae) em bovinos. Pesquisa Veterinária Brasileira 2011;31(1):59-64. doi:10.1590/S0100-736X2011000100009

Hunziker AT. Genera Solanacearum: the genera of Solanaceae illustrated, arranged according to a new system. Ruggell: A.R.G.Gantner Verlag; 2001.

Instituto Brasileiro de Geografia e Estatística - IBGE. Monografias municipais - Vitória da Conquista [internet]. 2015. [acesso em 25 out 2020]. Disponível em: https://biblioteca.ibge.gov.br/

Jaeger PML. Systematic studies in the genus Solanum in Africa [tese]. Birmingham: University of Birmingham; 1985.

Knapp S. Solanum Section Geminata (Solanaceae). Flora Neotropica 2002;84:1-401. 
Knapp S, Stehmann JR, Giacomin LL. New species, additions and a key to the Brazilian species of the Geminata clade of Solanum L. (Solanaceae) in Brazil. Phytokeys 2015a;47:1-48. doi: $10.3897 /$ phytokeys.47.9076

Knapp S, Barboza GE, Romero MV, Vignoli-Silva M, Giacomin LL, Stehmann JR. Identification and lectotypification of the Solanaceae from Vellozo's Flora Fluminensis 2015b;64(4):822-836. doi:10.12705/644.14

Lopes DCDXP, Freitas ZMF. Santos EP, Tomassini TCB. Atividades antimicrobiana e fototóxica de extratos de frutos e raízes de Physalis angulata L. Revista Brasileira de Farmacognosia 2006;16(2):206-210. doi: 10.1590/S0102-695X2006000200013

Luna-Cavazos M, Bye R. Phytogeographic analysis of the genus Datura (Solanaceae) in continental Mexico. Revista Mexicana de Biodiversidad 2011;82:977-988.

doi:10.22201/ib.20078706e.2011.3.720

Maia MR. Zoneamento geoambiental do município de Vitória da Conquista-BA: um subsídio ao planejamento [dissertação] Salvador, BA: Universidade Federal da Bahia; 2005.

Marinho JBR, Carvalho AU, Pierezan F, Keller KM, Riet-Correa F, Melo MM, Soto-Blanco B. Comparação dos efeitos das folhas de Cestrum axillare Vell. com as saponinas isoladas em caprinos. Pesquisa Veterinária Brasileira 2018;38(5):852-861. doi:10.1590/1678-5150-pvb-5244

Matias LJ, Rocha JA, Royo VA, Menezes EV, Melo-Júnior AF, Oliveira DA. Fitoquímica em espécies medicinais de Solanum L. (Solanaceae). Pesquisa em Farmacognosia 2019;11(1): 47-50.

Mendonça JL, Lopes JF. Coleção de germoplasma de espécies silvestres de Solanum da Embrapa. Documentos 168. Brasília: Embrapa Hortaliças; 2019.

Moraes AO, Melo E, Agra MF, França F. A família Solanaceae nos "inselbergues" do semi-árido da Bahia, Brasil. Iheringia, Série Botânica 2009;64(2):109-122.

More GK. A review pf the ethnopharmacology, phytochemistry and pharmacological relevance of the South African weed Solanum sisymbriifolium Lam. (Solanaceae). Environment, Development and Sustainability 2019;21:37-50.

Moreira HJC, Bragança HBN. Manual de identificação de plantas infestantes [internet]. São Paulo: FMC Agricultural Products; 2011. [acesso em 1 jun 2020]. Disponível em cana.com.br/biblioteca/informati vo/DO C-20160905WA0023.pdf

Moreira RCT, Costa LCB, Costa RCS, Rocha EA. Abordagem etnobotânica acerca do uso de plantas medicinais na Vila Cachoeira, Ilhéus, Bahia, Brasil. Acta Farmacêutica Bonaerense 2002;21(3):205-211.

Mori SA, Silva LAM, Lisboa G, Coradin L. Manual de manejo do herbário fanerogâmico. Centro de Pesquisa do Cacau, Ilhéus; 1989.

Nee M. Synopsis of Solanum section Acanthophora: a group of interest for glycoalkaloids. In: Hawkes G, Lester RN, Nee M, Estrada R, editors. Solanaceae III: Taxonomy, chemistry, evolution. Kew: Royal Botanical Gardens; 1991. p. 257-266.

Nee M. Synopsis of Solanum in the New World. In: Nee M, Symon DE, Lester RN, Jessop JP, editors. Solanaceae IV: Advances in biology and utilization. Kew: Royal Botanical Gardens; 1999. p. 285-333.

Olmstead RG. Phylogeny and biogeography in Solanaceae, Verbenaceae and Bignoniaceae: a comparison of continental and intercontinental diversification patterns. Botanical Journal of the
Linnean Society 2013;171(1): 80-102. doi:10.1111/i.1095$\underline{8339.2012 .01306 . \mathrm{x}}$

Olmstead RG, Bohs L, Migid HA, Santiago-Valentin E, Garcia VF, Collier SM. A molecular phylogeny of the Solanaceae. Taxon 2008;57(4):1159-1181. doi:10.1002/tax.574010

Pereira AC, Oliveira DF, Silva GH, Figueiredo HCP, Cavalheiro AJ, Carvalho DA, Souza LP, Chalfoun SM. Identification of the antimicrobial substances produced by Solanum palinacanthum (Solanaceae). Anais da Academia Brasileira de Ciências 2008;80(3):427-432. doi:10.1590/S0001-37652008000300004

Pereira LG, Vieira FJ, Alencar NL, Carvalho FPA, Barros RFM. Diversidade florística em quintais do Nordeste brasileiro: um estudo etnobotânico em comunidades rurais em Monsenhor Gil/PI. Espacios 2016;37(20):11.

Parreira MC, Hernandez DD, Giancotti PRF, Alves PLCA. Efeitos da densidade e do espaçamento de maria-pretinha (Solanum americanum Mill.) sobre a cultura do tomate. Revista Brasileira de Ciências Agrárias 2010;5(4):474-478. doi:10.5039/agraria.v5i4a772

Plowman TC, Knapp S, Press JR. A revision of the South American species of Brunfesia (Solanaceae). Fieldiana Botany. New series 1998;39:1-135. DOI: 10.5962/bhl.title.2618

Prefeitura Municipal de Vitória da Conquista - PMVC. Código Municipal do Meio Ambiente [Internet]. [Vitória da Conquista]: PMVC; 2007 [acesso em 15 maio 2020]. Disponível em: http://www.pmvc.ba.gov.br/

Prefeitura Municipal de Vitória da Conquista - PMVC. Plano Municipal de Saneamento Básico, produto 2.1 [internet]. [Vitória da Conquista]: PMVC; 2019 [acesso em 25 out. 2020]. Disponível em: http://www.pmvc.ba.gov.br/

Rodal MJN, Sales MF. Composição da flora vascular em um remanescente de floresta montana no semi-árido do nordeste do Brasil. Hoehnea 2007;34(4):433-446.

Ruszczyk A, Nascimento ES. Biologia dos adultos de Methona themisto (Hübner, 1818) (Lepidoptera, Nymphalidae, Ithomiinae) em praças públicas de Uberlândia, Minas Gerais, Brasil. Revista Brasileira de Biologia 1999;59(4):577-583. doi:10.1590/S003471081999000400007

Sampaio VS. O gênero Solanum L. (Solanaceae) na Floresta Atlântica ao norte do rio São Francisco [dissertação]. Recife, PE:

Universidade Federal de Pernambuco; 2013.

Sampaio VS, Vieira IMF, Lima-Júnior EA, Loiola MIB. Flora do Ceará, Brasil: Solanum (Solanaceae). Rodriguésia 2019;70(2):12-17. doi:10.1590/2175-7860201970029

Samuels J. Biodiversity of food species of the Solanaceae family: a preliminary taxonomic inventory of subfamily Solanoideae. Resources 2015;4(2):277-322. doi:10.3390/resources4020277

Santos ABN, Araújo MP, Sousa RS, Lemos JR. Plantas medicinais conhecidas na zona urbana de Cajueiro da Praia, Piauí, Nordeste do Brasil. Revista Brasileira de Plantas Medicinais 2016;18(2):442-450.

Santos ACJ, Melo JIM. Flora vascular de uma área de caatinga no estado da paraíba - nordeste do Brasil. Revista Caatinga 2010;23(2):32-40.

Santos SLDX, Alves RRN, Santos SLDX, Barbosa JAA, Brasileiro TF. Plantas utilizadas como medicinais em uma comunidade rural do semiárido da Paraíba, Nordeste do Brasil. Revista Brasileira de Farmácia 2012;93(1):68-79.

Särkinen T, Lynn B, Olmstead RG, Knapp S. A phylogenetic framework for evolutionary study of the nightshades (Solanaceae): a dated 1000-tip tree. BMC Evolutionary Biology 2013;13:214. doi:10.1186/1471-2148-13-214 
Sendtner O. Solanaceae et Cestrinneae. In: Martius CFP von, editor. Flora Brasiliensis. v. 6, pt. 10. Vindobonae et Lipsiae: Weinheim, J. Cramer 1846. p. 1-338.

Silva KN, Agra MF. Estudo farmacobotânico comparativo entre Nicandra physalodes e Physalis angulata (Solanaceae). Revista Brasileira de Farmacognosia 2005;15(4):344-351. doi:10.1590/S0102$\underline{695 \times 2005000400016}$

Silva KN, Agra MF, Baracho GS, Basílio IJLD. Estudo farmacobotânico de folhas de Nicotiana glauca (Solanaceae). Latin American Journal of Pharmacy 2007;26(4):499-506.

Silva NCB, Regis ACD, Almeida MZ. Estudo etnobotânico em comunidades remanescentes de quilombo em Rio de Contas Chapada Diamantina - Bahia. Fitos 2012;7(2):99-109.

Silva PH, Oliveira YR, Abreu MC. Uma abordagem etnobotânica acerca das plantas úteis cultivadas em quintais em uma comunidade rural do semiárido piauiense, Nordeste do Brasil. Journal of Environmental Analysis and Progress 2017;2(2):144-159. doi:10.24221/jeap.2.2.2017.1179.115-124

Silva SC, Carvalho AMV, Santos FAR. Cestrum L. (Solanaceae) da mata higrófila do Estado da Bahia, Brasil. Acta Scientiarum, Biological Sciences 2003;25(1):157-166. DOI:

10.4025/actascibiolsci.v25i1.2112

Silva SN, Carvalho AMV, Santos FAR. Cestrum salzmannii Dunal (Solanaceae): espécie endêmica da Bahia. Agrotrópica 2002;14(2):49-54.

Simpson MG. Plant Systematics. 2nd ed., San Diego: Elsevier Academic Press, 2010.

Singh LR, Singh OM. Datura stramonium: an overview of its phytochemistry and pharmacognosy. Research Journal of Pharmacognosy and Phytochemistry 2013;5(3):143-148.

Soares ELC, Vendruscolo GS, Vignoli-Silva M, Thodes VA, Silva JG, Mentz LA. O gênero Physalis L. (Solanaceae) no Rio Grande do Sul, Brasil. Pesquisas Botânicas 2009;(60):323-340.

Soares ELC, Vignoli-Silva M, Vendruscolo GS, Thode VA, Silva JG, Mentz LA. A família Solanaceae no Parque Estadual de Itapuã, Viamão, Rio Grande do Sul, Brasil. Revista Brasileira de Biociências 2008;6(3):177-188.

Soares-Filho AO, Paula A, Santos AD, Oliveira CV, D’Soares CS, Santos FS, Carvalho RCF, Pereira JES. Plantas ruderais no Planalto Conquistense, Bahia e sua importância. Natureza online 2016;14(2):27-43.

Soni P, Siddiqui AA, Dwivedi J, Soni, V. Pharmacological properties of Datura stramonium L. as a potential medicine tree: an overview. Asian Pacific Journal of Tropical Biomedicine 2012;2(12):10021008. doi:10.1016/S2221-1691(13)60014-3

Srivastava S, Dvivedi A, Shukla RP. Solanum sisymbriifolium Lam. (Solanaceae): a new invasive undershrub of the old-fields of northeastern Uttar Pradesh. CheckList 2015;11(3):1643. doi: $10.15560 / 11.3 .1643$

Stehmann JR. Estudos taxonômicos na tribo Nicotianeae G.Don (Solanaceae): revisão de Petunia Jussieu, das espécies brasileiras de Calibrachos La Llave \& Lexarza e o estabelecimento do novo gênero Petuniopsis Stehmann \& Semir [tese]. Campinas, SP: Universidade Estadual de Campinas; 1999.
Stommel JR, Bosland PW. Ornamental pepper. In: Anderson NO, editors. Flower breeding and genetics. Springer; 2007. p. 561-569. doi:10.1007/978-1-4020-4428-1 21

Superintendência de estudos econômicos e sociais da Bahia - SEI. Físico-ambientais - Mapas estaduais [internet]. [Salvador]: SEI; 1998 [acesso em 25 out 2020]. Disponível em: https://www.sei.ba.gov.br/

Terço JW, Lima RA. Identificação das classes de metabólitos secundários no extrato etanólico dos frutos e folhas de Solanum paniculatum L. South American Journal of Basic Education, Technical and Technological 2016;3(2):92-99.

Thièrs B. Index herbariorum: a global directory of public herbaria and associated staff [internet]. New York: New York Botanical Garden's Virtual Herbarium [continuously updated (acesso em 23 out 2020)]. Disponível em: http://sweetgum.nybg.org/ih/

Vellozo JMC. Flora Fluminensis. Archivos do Museu Nacional do Rio de Janeiro 1831;5:78-86.

Verçoza FC, Dias AR, Missagia CC. Ecologia da polinização e potenciais dispersores da "marianeira" - Acnistus arborescens (L.) Schltdl. (Solanaceae) em área de Floresta Atlântica do Rio de Janeiro. Natureza Online 2012;10(2):59-64.

Vignoli-Silva M. O gênero Cestrum L. (Solanaceae) no Brasil extraamazônico [tese]. Porto Alegre, RS: Universidade Federal do Rio Grande do Sul; 2009.

Vignoli-Silva M, Mentz LA. O gênero Nicotiana L. (Solanaceae) no Rio Grande do Sul, Brasil. Iheringia 2005;60(2):151-173.

Wang LQ, Wang Y, Gao SY, Zhu LH, Wang F, Li H, Chen, LX. Phenolic amides with anti-Parkinson's disease (PD) effects from Nicandra physaloides. Journal of Functional Foods 2017;31:229-236. doi:10.1016/j.jff.2017.01.045

Zappi DC, Lucas E, Stannard BL, Lughadha EN, Pirani JR, Queiroz LP, Atkins S, Hind DJN, Giullieti AM, Harley RM, Carvalho AM. Lista das plantas vasculares de Catolés, Chapada Diamantina, Bahia, Brasil. Boletim de Botânica da USP 2003;21(2):345-398. doi:10.11606/issn.2316-9052.v21i2p345-398

\section{Como citar este artigo \\ How to cite this article:}

$(\mathrm{ABNT})$

MOURA, J.N.; CAIRES, C.S. A família Solanaceae Juss. no município de Vitória da Conquista, Bahia, Brasil. Paubrasilia, Porto Seguro, v. 4, e0049, 2021. DOI: 10.33447/paubrasilia.2021.e0049

(Vancouver)

Moura JN, Caires CS. A família Solanaceae Juss. no município de Vitória da Conquista, Bahia, Brasil. Paubrasilia 2021;4:e0049. doi:10.33447/paubrasilia.2021.e0049 